\title{
Visualization of O-2A Progenitor Cells in Developing and Adult Rat Optic Nerve by Quisqualate-stimulated Cobalt Uptake
}

\author{
Barbara P. Fulton, ${ }^{1}$ Julia F. Burne, ${ }^{2}$ and Martin C. Raff ${ }^{2}$ \\ 'Department of Anatomy and Developmental Biology, and ${ }^{2} \mathrm{MRC}$ Developmental Neurobiology Programme, Department \\ of Biology, Medawar Building, University College London, London WC1E 6BT, United Kingdom
}

\begin{abstract}
Some macroglial cells of the 0-2A lineage express glutamate receptor channels of the quisqualate/kainate type and take up extracellular cobalt when activated by glutamate agonists. These cells can be identified both in vitro and in situ following precipitation and intensification of the intracellular cobalt. We have used this technique to characterize these cells in the developing and adult rat optic nerve. In purified cultures of optic nerve cells, 0-2A progenitor cells and type 2 astrocytes took up cobalt in the presence of quisqualate, while oligodendrocytes, type 1 astrocytes, and microglial cells did not. When whole optic nerves of various postnatal ages were exposed to quisqualate and cobalt, a subpopulation of glial cells took up cobalt. Cobalt uptake in vitro and in situ was blocked by 6-cyano-7-nitroquinoxaline-2,3-dione. The number, morphology, and spatial distribution of cobaltfilled cells in situ varied with age. In perinatal nerves, $9 \%$ of glial cells took up cobalt. These cells had a simple unipolar or bipolar morphology and were two to three times more concentrated at the chiasm end than at the eye end of the nerve. During subsequent development, this gradient disappeared and the cobalt-filled cells became progressively more complex in morphology and increased in number and density, reaching a peak toward the end of the second postnatal week. The number subsequently declined to about $16,000(7 \%)$ in the adult nerve. The processes of some cobalt-filled cells appeared to contact nodes of Ranvier. All cobalt-filled cells in 21/2-week-old optic nerves had a similar ultrastructural appearance and did not resemble either mature oligodendrocytes or astrocytes. Our results suggest that the cells stimulated by quisqualate to take up cobalt in the optic nerve are the in vivo counterpart of 0-2A progenitor cells. We found no evidence that any of these cells are type 2 astrocytes.
\end{abstract}

Dissociated cell cultures of perinatal rat optic nerve contain three kinds of differentiated macroglial cells: oligodendrocytes and two types of astrocytes (reviewed in Raff, 1989). In such

\footnotetext{
Received Oct. 3, 1991; revised June 26, 1992; accepted July 6, 1992.

We thank Becky Pruss for introducing us to the cobalt technique and Barbara Barres for providing the purified optic nerve glial cells. We also thank Jennifer Altman, Barbara Barres, Stuart Cull-Candy, Durward Lawson, Mark Noble, John Scholes, Jim Voyvodic, Guus Wolswijk, and David Wyllie for helpful discussions and suggestions. This work was supported by the Medical Research Council, United Kingdom.

Correspondence should be addressed to B. P. Fulton, Department of Anatomy and Developmental Biology, University College London, Gower Street, London WC1E 6BT, U.K.

Copyright (C) 1992 Society for Neuroscience $0270-6474 / 92 / 124816-18 \$ 05.00 / 0$
}

cultures, type 1 astrocytes develop from their own precursor cells (Raff et al., 1984), thought to be the neuroepithelial cells that form the optic stalk (Small et al., 1987), whereas both oligodendrocytes and type 2 astrocytes develop from bipotential precursor cells (Raff et al., 1983), referred to as O-2A progenitor cells, which are thought to migrate into the optic nerve early in development (Small et al., 1987). Studies using antibodies to identify the three macroglial cell types in cell suspensions of developing optic nerve have suggested that type 1 astrocytes first appear on embryonic day 16, oligodendrocytes around birth, and type 2 astrocytes during the second postnatal week (Miller et al., 1985). Type 1 astrocytes play an important part in regulating the development of O-2A progenitor cells in culture, influencing both the proliferation of the progenitor cells and their differentiation into type 2 astrocytes (reviewed in Raff, 1989; Lillien and Raff, 1990; Richardson et al., 1991).

O-2A progenitor cells are present in adult as well as immature optic nerves (ffrench-Constant and Raff, 1986a; Wolswijk and Noble, 1989), but those in adult nerves have a different morphology, antigenic phenotype, cell cycle time, differentiation rate, and migration rate from those in perinatal nerves (Wolswijk and Noble, 1989). Adult O-2A progenitor cells are thought to arise from a subset of perinatal O-2A progenitor cells (Noble et al., 1989) beginning at about postnatal day 7 (P7); they increase gradually in number, becoming the predominant form by about 1 month after birth (Wolswijk et al., 1990). Unlike perinatal $\mathrm{O}-2 \mathrm{~A}$ progenitor cells, they seem to have the capacity for extensive self-renewal (Wren et al., 1992).

Whereas a good deal has been learned about the properties and development of optic nerve glial cells in culture, much less is known about these cells in vivo. A major difficulty has been the lack of definitive markers for distinguishing among the different cell types in situ. In particular, it has not been possible thus far to identify unambiguously $\mathrm{O}-2 \mathrm{~A}$ progenitor cells or type 2 astrocytes in the intact optic nerve. In the present study, we have taken advantage of two previous sets of observations in order to visualize $\mathrm{O}-2 \mathrm{~A}$ lineage cells in the developing and adult rat optic nerve. First, in culture, both $\mathrm{O}-2 \mathrm{~A}$ progenitor cells and type 2 astrocytes express glutamate receptor-linked cation channels of the quisqualate/kainate (non-NMDA) type (Cull-Candy et al., 1989; Usowicz et al., 1989; Barres et al., 1990a; Wyllie et al., 1991); O-2A progenitor cells also express these channels in vivo (Barres et al., 1990a). Second, Pruss et al. (1991) have shown that glutamate and quisqualate (QUIS), but not NMDA, stimulate certain CNS cells, including some $\mathrm{O}-2 \mathrm{~A}$ lineage cells, to take up extracellular cobalt; these cells can then be visualized, either in vitro or in situ, by precipitation and silver enhancement 
of the intracellular cobalt. A similar cobalt labeling procedure was originally developed by Hogan (1983) for visualizing capsaicin-sensitive sensory neurons. In the present study, we have used a further modification of the procedure on optic nerve cells to visualize $\mathrm{O}-2 \mathrm{~A}$ lineage cells both in vitro and in situ, and have characterized the postnatal development of these cells in situ.

\section{Materials and Methods}

Optic nerve dissection. Optic nerves were dissected from Sprague-Dawley rats aged from postnatal day 0 ( $\mathrm{P} 0$ ) to adult ( $\geq 3$ months). Between $\mathrm{P} 0$ and $\mathrm{P} 21$, rats were killed by decapitation (under carbon dioxide anaesthesia when $\mathrm{P} 14$ or older), and at older ages, by cervical dislocation under carbon dioxide anesthesia. Nerves were cut behind the eye and dissected out together with the chiasm.

Optic nerve transection. Four animals aged 4-6 weeks, were anesthetized by intraperitoneal injection of Hypnorm (Jensson; $0.3 \mathrm{ml} / \mathrm{kg}$ ) and diazepam $(2.5 \mathrm{mg} / \mathrm{kg})$ and the left optic nerve was transected behind the eye as previously described (Miller et al., 1986). The right nerve was left intact to serve as a control. After 6-7 d, the animals were killed and control and transected nerves were dissected out as described above.

Cell purification. Purified cultures of O-2A progenitor cells, oligodendrocytes, type 2 astrocytes, and microglial cells were kindly supplied by Barbara Barres (Department of Biology, University College, London) following an immunopanning purification procedure. A full account of these immunopanning methods will be published elsewhere (B. Barres and M. C. Raff, unpublished observations); until then, detailed protocols can be obtained from B. Barres. In brief, cells were dissociated from P7 optic nerves using papain (Huettner and Baughman, 1986; Barres et al., 1990 a) and were immunopanned in a four step procedure by sequentially incubating the cells in a series of monoclonal antibody-coated bacteriologic dishes. The sequence of monoclonal antibodies used was as follows: (1) HO-13-4 (an IgG anti-Thy 1.2 antibody) (Marshak-Rothstein et al., 1979), to bind microglial cells via their Fc receptors; (2) anti-Ran-2 (Bartlett et al., 1981), to bind type 1 astrocytes and meningeal cells; (3) anti-galactocerebroside (GC) (Ranscht et al., 1982), to bind oligodendrocytes, and (4) A2B5 (Eisenbarth et al., 1979), to bind O-2A progenitor cells. Following each step, nonadherent cells were transferred to the next dish in the sequence, while the adherent cells were removed from the dish by treatment with trypsin $(0.125 \%)$ in $\mathrm{Ca}^{2+}$ and $\mathrm{Mg}^{2+}$-free medium. Purified microglial cells, oligodendrocytes, and $\mathrm{O}-2 \mathrm{~A}$ progenitor cells were obtained by removing cells after steps 1,3 , and 4 , respectively.

Type 2 astrocytes were prepared as follows. Cells were dissociated from $P 9$ optic nerves and were cultured in $75 \mathrm{~cm}$ poly-L-lysine-coated flasks for $5 \mathrm{~d}$ in Dulbecco's modified Eagle's medium containing 10\% fetal calf serum (DMEM-FCS). They were then removed from the flasks by treatment with trypsin $(0.125 \%)$ in $\mathrm{Ca}^{2+}$ - and $\mathrm{Mg}^{2+}$-free medium and incubated in an anti-GC-antibody-coated bacteriologic dish to remove oligodendrocytes and macrophages from the cell suspension. The nonadherent cells were transferred to a dish coated with the $\mathrm{O} 4$ monoclonal antibody (Sommer and Schachner, 1981); many type 2 astrocytes adhered to this dish and, after washing off the nonadherent cells, could be removed from the dish by treatment with trypsin as above.

The cells obtained by sequential immunopanning were more than $90 \%$ pure when assessed by antibody staining (see below)

Enriched cultures of cortical type 1-like astrocytes were prepared as previously described (Janzer and Raff, 1987). Between 90\% and 95\% of these cells werc glial fibrillary acidic protein-positive $\left(\right.$ GFAP $\left.^{+}\right)$, and all of these were A2B5- (see below).

Cell culture. Cells were cultured on poly-D-lysine-coated glass coverslips as previously described (Raff et al., 1985). Unpurified P7 optic nerve cells, purified optic nerve type 2 astrocytes and microglial cells, and cortical type 1-like astrocytes were cultured in DMEM-FCS. Purified O-2A progenitor cells were cultured in serum-free medium (SFmedium) [modified from Bottenstein and Sato (1979) as previously described; Lillien et al., 1988], containing human platelet-derived growth factor (PDGF; R \& D Systems, Inc.; $2 \mathrm{ng} / \mathrm{ml}$ ) and bovine basic fibroblast growth factor (basic FGF; R \& D Systems, Inc.; $10 \mathrm{ng} / \mathrm{ml}$ ). Purified oligodendrocytes were cultured in SF-medium alone. The cell types in the cultures were assessed by indirect immunofluorescence, using A2B5 (Eisenbarth et al., 1979) and anti-GC (Ranscht et al., 1982) monoclonal antibodies, and anti-GFAP scrum (Pruss, 1979) as previously described (Raff et al., 1985): O-2A progenitor cells are A2B5+, $\mathrm{GC}^{-}, \mathrm{GFAP}^{-}$; oligodendrocytes are $\mathrm{GC}^{+}$; type 2 astrocytes are $\mathrm{A} 2 \mathrm{~B}^{+}{ }^{+}, \mathrm{GFAP}^{+}$; type 1 astrocytes are A2B5 ${ }^{-}$, GFAP+ $^{+}$(Raff et al., 1983).

QUIS-induced cobalt uptake in whole optic nerve. Optic nerves of different ages were incubated for $30 \mathrm{~min}$ at room temperature $\left(20-25^{\circ} \mathrm{C}\right)$ in cobalt assay buffer (CAB), which had the following composition (modified from Pruss et al., 1991): $137 \mathrm{~mm}$ sucrose, $50 \mathrm{~mm} \mathrm{NaCl}, 4$ mм KCl, $1 \mathrm{~mm} \mathrm{MgCl}, 10 \mathrm{~mm}$ glucose, and $10 \mathrm{~mm}$ IIEPES, pH 7.2. They were then transferred to $\mathrm{CAB}$ containing $5 \mathrm{~mm} \mathrm{CoCl}_{2}$ and the glutamate agonist QUIS (Tocris; $100 \mu \mathrm{M}$ ) for $30 \mathrm{~min}$ at room temperature and washed three times in $\mathrm{CAB}$, each for $10 \mathrm{~min}$. The same procedure was used for transected nerves. In some experiments, the glutamate antagonist 6-cyano-7-nitroquinoxaline-2,3-dione (CNQX; Tocris; $100 \mu \mathrm{M}$ ) was added during, and for $15 \mathrm{~min}$ before and after, treatment with QUIS and cobalt, or other glutamate agonists were tested in place of QUIS, including kainate (Tocris; $100 \mu \mathrm{M}$ ), glutamate (Sigma; $100 \mu \mathrm{M}),(S)-\alpha$-amino-3-hydroxy-5-methyl-4-isoazole propionic acid (AMPA; Tocris; $100 \mu \mathrm{M}$ ), and $N$-methyl-D-aspartate (NMDA; Tocris; $100 \mu \mathrm{M})$; NMDA was applied in the absence of $\mathrm{Mg}^{2+}$ and in the presence of glycine (Tocris; $1 \mu \mathrm{M}$ ) (Ascher and Nowak, 1987). In other experiments, agonists were omitted in order to assay for nonspecific uptake of cobalt. To check whether any of the cobalt uptake in the absence of added agonist might be stimulated by endogenous glutamate, some nerves were incubated in CNQX for $30 \mathrm{~min}$ before, during, and after exposure to cobalt.

Light microscopy. To prepare them for light microscopy, nerves that had been incubated in cobalt and QUIS were placed in $1.2 \%$ ammonium sulfide for $10 \mathrm{~min}$ to precipitate the intracellular cobalt as cobaltous sulfide (Pitman et al., 1972), and then washed in CAB for $10 \mathrm{~min}$ and immersion fixed in acid/alcohol $(5 \% / 95 \%)$ for $10 \mathrm{~min}$ at $-20^{\circ} \mathrm{C}$. They were then rehydrated through graded alcohols and incubated in $\mathrm{CAB}$ at room temperature for $10 \mathrm{~min}$. Silver intensification of the cobaltous sulfide precipitate was carried out as described by Davis (1982). Intensification was stopped after 5-10 min by washing in CAB for $10 \mathrm{~min}$. For examination as whole-mounts, the nerves were dehydrated for a second time through graded alcohols, cleared in methyl salicylate, and mounted in DPX mountant. Alternatively, nerves were prepared for cutting into frozen, wax, or plastic sections. For frozen sections, the nerves were embedded in OCT compound (Tissue-Tek) and frozen in liquid nitrogen, and 10 or $20 \mu \mathrm{m}$ sections were cut on a Bright cryostat, collected on gelatin-coated slides, and mounted in glycerol [9:1 in phosphate-buffered saline (PBS)]. For wax sections $(20 \mu \mathrm{m})$, nerves were processed as for whole-mounts, except that they were cleared in xylene and then embedded in paraffin wax (Paraplast). For plastic sections, nerves were processed and embedded as for electron microscopy (EM; see below) and $2 \mu \mathrm{m}$ longitudinal sections were cut on an LKB ultramicrotome. Whole-mounts and sections were examined with a Zeiss photomicroscope and photographed with Tri-X film rated 400 ASA. In some cases, camera lucida drawings of cobalt-filled cells were made using a Wild M20 microscope.

Electron microscopy. For electron microscopy, P18 or adult nerves that had been incubated in cobalt and QUIS were treated with $1.2 \%$ ammonium sulfide for $10 \mathrm{~min}$ as described above, washed three times in CAB ( $5 \mathrm{~min}$ each), and immersion fixed overnight at $4^{\circ} \mathrm{C}$ in $2.5 \%$ glutaraldehyde in $300 \mathrm{mOsm}$ Millonig's buffer. They were then washed in veronal acetate buffer (VAB) for $15 \mathrm{~min}$ at room temperature before postfixing in $1 \%$ osmium tetroxide in VAB for $10 \mathrm{~min}$ at room temperature. After washing in VAB for $15 \mathrm{~min}$, they were dehydrated in acetone and rehydrated through graded alcohols. Silver intensification of the cobalt sulfide precipitate was carried out as for light microscopy and stopped after $10 \mathrm{~min}$ by washing in $\mathrm{V} \Lambda \mathrm{B}$. The nerves were incubated overnight at $4^{\circ} \mathrm{C}$ in a saturated solution of uranyl acetate in $\mathrm{VAB}$, after which they were washed in distilled water, dehydrated through graded alcohols, impregnated with propylene oxide, and embedded in EPON 812. Longitudinal or transverse thin sections were cut on an LKB ultramicrotome, counterstained with uranyl acetate and lead citrate, and examined on a Jeol $100 \mathrm{CK}$ microscope at $80 \mathrm{kV}$.

Intracellular injection of horseradish peroxidase. In some P14 optic nerves, glial cells were injected intracellularly with horseradish peroxidase (HRP) as described in Miller et al. (1989). The nerves were then immersion fixed in acid/alcohol $(5 \% / 95 \%)$ for $10 \mathrm{~min}$ at $-20^{\circ} \mathrm{C}$ and rehydrated through graded alcohols. The HRP reaction product was obtained using the pyrocatechol $/ p$-phenylenediamine method described by Hanker et al. (1977), and whole-mounts of the nerves were prepared as described above.

Estimation of cell numbers. To obtain estimates of the total number 

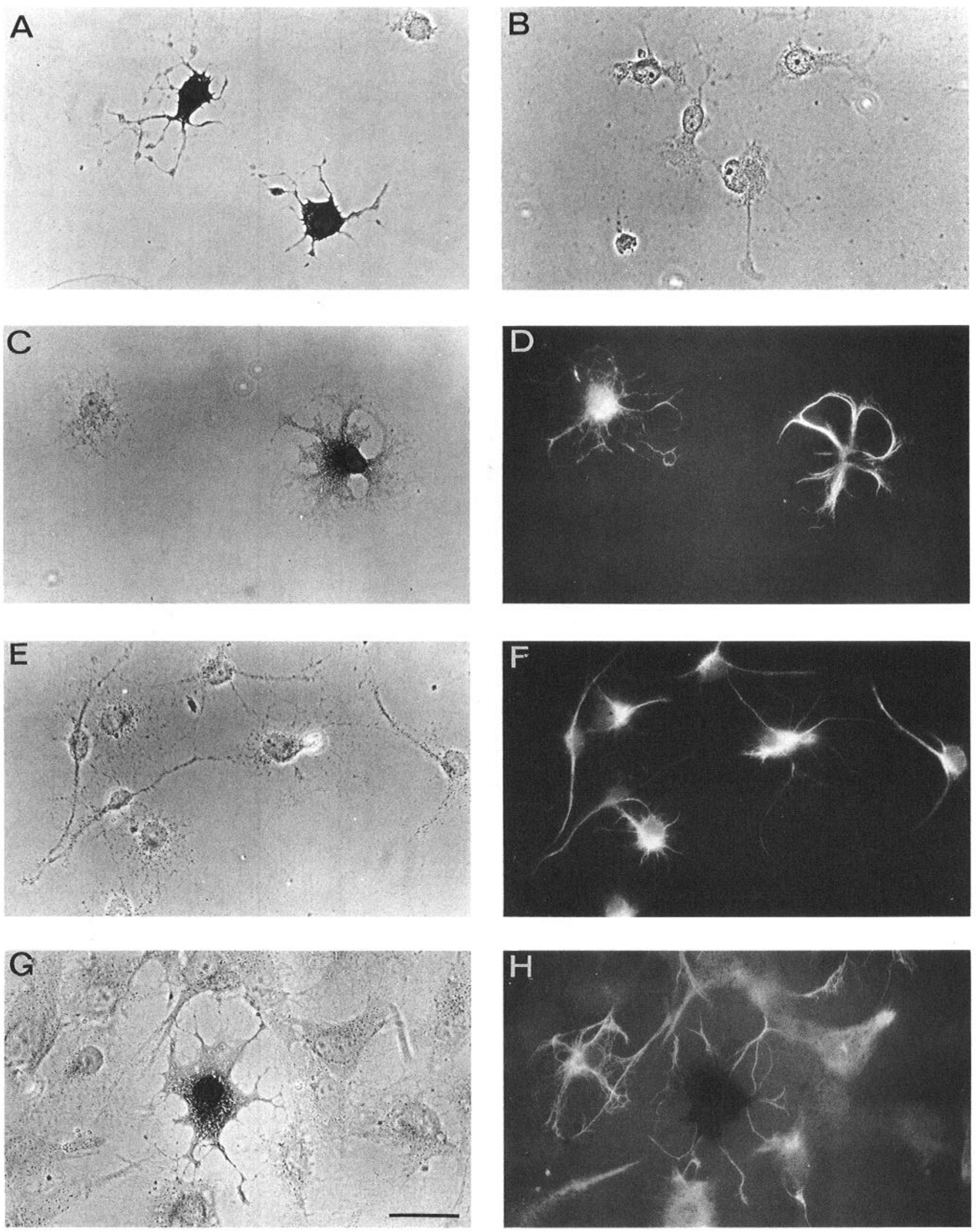

Figure 1. QUIS-induced cobalt uptake in O-2A lineage cells in culture. Purified O-2A progenitor cells $(A$ and $B)$, purified type 2 astrocytes $(C-F)$, and P2 optic nerve cells $(G$ and $H)$ were cultured for $2-3 \mathrm{~d}$, exposed to QUIS $(100 \mu \mathrm{M})$ and cobalt $(5 \mathrm{~mm})$ in the presence $(B, E, F)$ or absence $(A$, $C, D, G, H)$ of CNQX $(100 \mu \mathrm{M})$, and then processed as described in Materials and Methods. In $C-H$, the cells were stained for GFAP. The cells were photographed using phase-contrast $(A-C, E, G)$ or fluorescence optics $(D, F, H)$. Note that a proportion of O-2A progenitor cells $(A)$ and type 2 astrocytes $(C, D, G, H)$, but not type 1 astrocytes $(G, H)$, were induced by QUIS to take up cobalt and that this uptake was inhibited by CNQX $(B, E, F)$. Scale bar, $30 \mu \mathrm{m}$. 
of cobalt-filled glial cells in nerves from P1 to P31, low-power camera lucida drawings were made of transverse or longitudinal sections of QUIS-treated nerves, marking the location of cobalt-filled cell bodies for subsequent counting. At P14 and older, when cobalt-filled cells are evenly distributed along the nerve, the total number of cobalt-filled glial cell profiles was counted in each of five $20 \mu \mathrm{m}$ transverse sections (wax or frozen) and the mean number per section was calculated. The total number of cobalt-filled cells per nerve was estimated from this value by extrapolating from the volume of the section to the total volume of the nerve; the dimensions used to calculate total nerve volume at different ages are given in the Figure 5 caption. Since some cells will span more than one section, this number is an overestimate of the true number of cobalt-filled cells per nerve. To account for this, a correction factor based on the section thickness and mean cell diameter was applied (Abercrombie, 1946). At P1 and P8, counts of cobalt-filled glial cells were made in five $2 \mu \mathrm{m}$ longitudinal plastic sections each separated by at lcast $10 \mu \mathrm{m}$. Since there is a rostrocaudal gradient of cells at this stage (see below), we selected sections that spanned the entire length of the nerve. The total number of cobalt-filled cells per nerve was estimated and corrected as above. At P1 and P8, when some glial cells were found to take up cobalt nonspecifically (see below), the number of cobalt-filled glial cells was also estimated, as above, in two nerves treated with QUIS and cobalt in the presence of CNQX. This number was then subtracted from the values obtained in the absence of CNQX to give the number of cells that took up cobalt via a CNQX-sensitive mechanism.

We used similar procedures to those described above to obtain estimates of the total number of glial cells per nerve, using the data plotted in Figure 19 of Vaughn (1969); these estimates were then used to calculate the percentage of glial cells in the nerve that took up cobalt.

QUIS-induced cobalt uptake in cultured cells. The procedure was the same as that described above for light microscopy of whole nerves, except that the incubation in agonist and cobalt was carried out at $37^{\circ} \mathrm{C}$, the ammonium sulfide was used at $1.2 \%$ for $2 \mathrm{~min}$, and cells were mounted in glycerol (in PBS, 9:1). In some experiments, the cells were labeled with anti-GFAP antiserum before they were mounted.

\section{Results}

\section{QUIS-induced cobalt uptake into O-2A lineage cells in}

culture

When cultures of P7 optic nerve cells were exposed simultaneously to QUIS and cobalt after $\mathbf{3} \mathrm{d}$ in vitro, only cells with the process-bearing morphology of O-2A lineage cells (Raff et al., 1983) were found to take up detectable amounts of cobalt (not shown). In order to establish which cell types take up cobalt under these conditions, we studied cultures of purified glial cells. All cultures were more than $90 \%$ pure as assessed by immunostaining (see Materials and Methods). O-2A progenitor cells in cell suspensions prepared from $\mathrm{P} 7$ optic nerves were purified by sequential immunopanning and cultured for $2-3 \mathrm{~d}$ in SFmedium in the presence of PDGF and FGF to prevent them from differentiating into oligodendrocytes (Bögler et al., 1990). When exposed simultaneously to QUIS and cobalt, approximately $25 \%$ of these cells were found to contain readily detectable amounts of cobaltous sulfide precipitate following silver intensification (Fig. 1A). Hereafter, we shall refer to this silverintensified precipitate simply as cobalt. The intensity of the intracellular cobalt varied greatly from cell to cell, ranging from just detectable (pale brown) to dense black. By contrast, if the QUIS antagonist CNQX was present during the QUIS treatment, $<1 \%$ of O-2A progenitor cells in vitro took up cobalt (Fig. $1 B$, Table 1). It therefore appears that entry of cobalt into these cells requires activation of QUIS receptors. When $\mathrm{GC}^{+}$oligodendrocytes were purified by immunopanning and tested in the same way, $\leq 2 \%$ of the cells were induced to take up cobalt (Table 1). In order to study type 2 astrocytes, P7 optic nerve cells were cultured in $10 \%$ FCS to induce the progenitor cells to differentiate into type 2 astrocytes (Raff et al., 1983); after 4 $\mathrm{d}$, the $\mathrm{O}^{+}$type 2 astrocytes were purified by immunopanning
Table 1. Proportion of glial cells in culture that are stimulated by QUIS to take up cobalt

\begin{tabular}{lll} 
& CNQX & $\begin{array}{l}\text { Proportion } \\
\text { (\%) of cells } \\
\text { containing } \\
\text { cobalt }\end{array}$ \\
\hline Cells & - & $27 \pm 5$ \\
Purified O-2A progenitors & + & $<1$ \\
Purified oligodendrocytes & - & $2 \pm 0.5$ \\
Purified type 2 astrocytes & + & $<1$ \\
Cortical type 1-like astrocytes & - & $18 \pm 3$ \\
Purified microglial cells & + & $<1$ \\
& - & $<1$ \\
& + & $<1$ \\
\hline
\end{tabular}

Purified O-2A lineage cells were prepared from P7 optic nerve (by immunopanning as described in Materials and Methods) and cultured for 2-3 d in SF-medium containing PDGF and FGF (for O-2A progenitor cells), in SF-medium alone (for oligodendrocytes), or in DMEM-FCS (for type 2 astrocytes). Enriched type 1-like astrocytes were prepared as previously described (Jancer and Raff, 1987). All cultures were more than $90 \%$ pure when assessed by immunostaining. The cells were treated with QUIS and cobalt, with or without CNQX, and then processed as described in Materials and Methods. The results are expressed as means $\pm S D$ of at least three cultures.

and cultured in $10 \%$ FCS for a further $2 \mathrm{~d}$. Approximately $20 \%$ of these cells were stimulated by QUIS to take up cobalt (Fig. $1 C, D)$ and this proportion fell to $<1 \%$ in the presence of CNQX (Fig. $1 E, F$; Table 1).

Astrocytes were also tested in two other kinds of cultures. First, P2 optic nerve cells were cultured in 10\% FCS for $3 \mathrm{~d}$ and then assayed for cobalt uptake before they were immunolabeled for GFAP.In such cultures, approximately $25 \%$ of the GFAP+ cells with the process-bearing morphology of type 2 astrocytes were induced by QUIS to take up cobalt, whereas $<1 \%$ of the $\mathrm{GFAP}^{+}$cells with the fibroblast-like morphology of type 1 astrocytes were so induced (Fig. $1 G, H$ ); in the presence of CNQX, $\leq 1 \%$ of the process-bearing astrocytes were induced by QUIS to take up cobalt (not shown). Although cobalt-filled glial cells in culture could be labeled with anti-GFAP antibodies using immunofluorescence (see Fig. $1 C-H$ ), the fluorescent signal was severely quenched by the cobalt. Second, in cultures of purified type 1-like astrocytes prepared from neonatal cerebral cortex, $<1 \%$ of the cells were stimulated by QUIS to take up cobalt (Table 1).

In addition to these various types of macroglial cells, we also examined the ability of microglial cells to take up cobalt in response to QUIS stimulation in vitro. Less than $1 \%$ of microglial cells purified from P7 optic nerve by immunopanning were stimulated by QUIS to take up cobalt (Table 1).

\section{QUIS-induced cobalt uptake in whole optic nerves}

When whole optic nerves of various postnatal ages were exposed simultaneously to QUIS and cobalt, a subpopulation of glial cells in whole-mount preparations were labeled with cobalt (Fig. 2). As in cultured cells, the intensity of cobalt labeling, at all ages, varied greatly from cell to cell. In P14 or older nerves, cobalt uptake into glial cells required activation of glutamate receptors and was negligible in nerves treated only with cobalt or in nerves treated with cobalt and QUIS in the presence of CNQX (Fig. $2 F$ ). Moreover, if nerves were treated with QUIS 

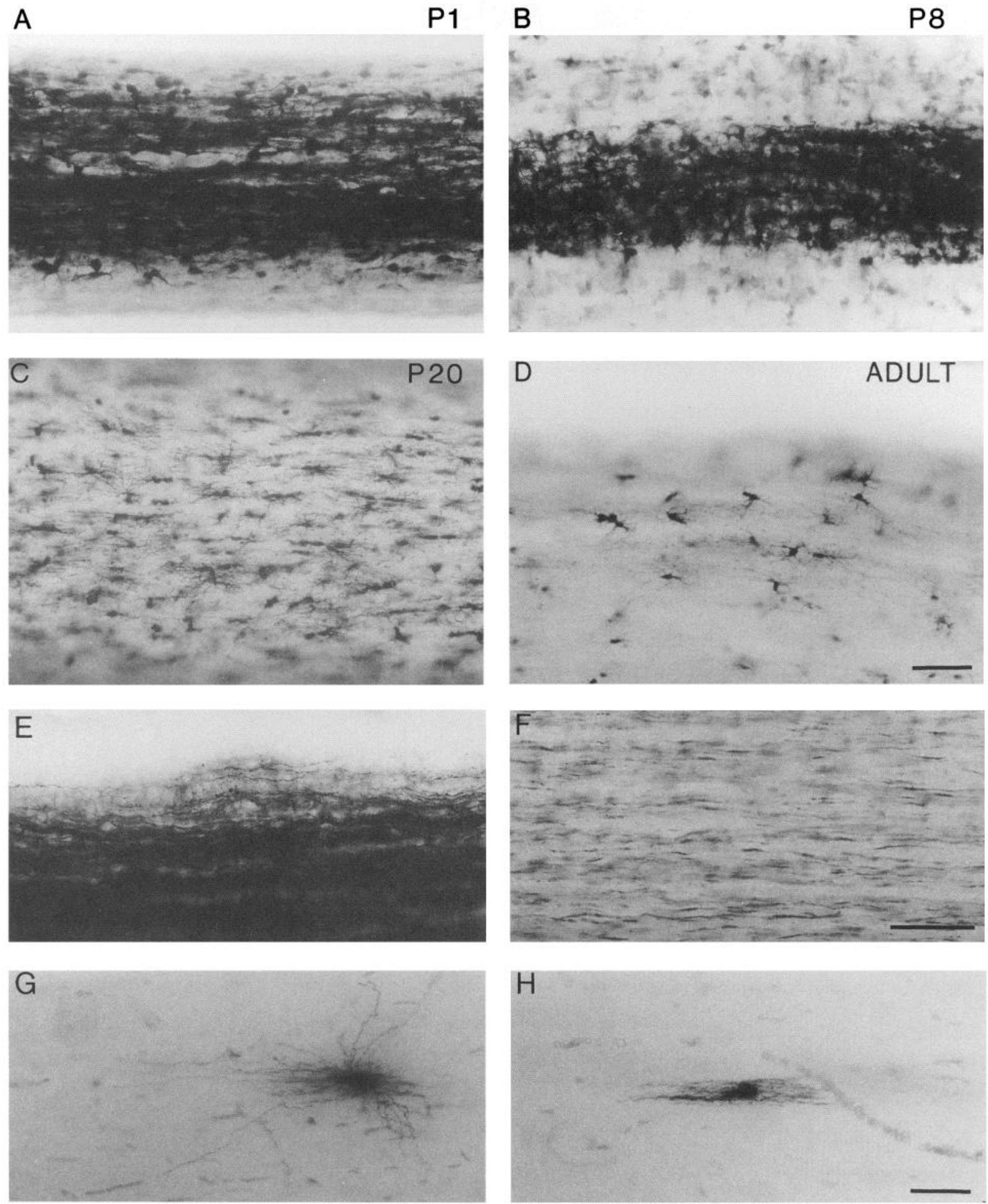

Figure 2. Whole-mounts of optic nerves of different ages treated with QUIS and cobalt. In all micrographs, the longitudinal axis of the nerve runs horizontally. A, P1 nerve. Simple unipolar or bipolar cells can be seen in the peripheral regions of the nerve; in the core of the nerve they are largely obscured by the large numbers of cobalt-filled axons. $B$, P8 nerve. Cobalt-filled cells have increased in both density and morphological complexity. Axonal uptake of cobalt is still evident in the core of the nerve. $C$, P20 nerve. Cobalt-filled cells have further increased in complexity, but decreased in density. At this stage, axonal uptake of cobalt is confined to nodes of Ranvier. $D$, Adult nerve. The density of cobalt-filled cells has further decreased and the cells have much longer and finer processes. $E$ and $F$, Whole-mounts of P8 $(E)$ and adult $(F)$ optic nerves treated with QUIS and cobalt in the presence of CNQX. In $E$, axonal uptake of cobalt is still present, but no glial cells contain cobalt; in $F$, cobalt uptake is confined to the nodal regions of axons. $G$ and $H$, A longitudinally oriented astrocyte-like cell $(G)$ and an oligodendrocyte $(H)$ visualized by intracellular injection of HRP in P14 nerves. Same magnification as $A-D$. Note the difference in size and morphology between these cell types and the cobalt-filled glial cells. Scale bars, $50 \mu \mathrm{m}$. 
A

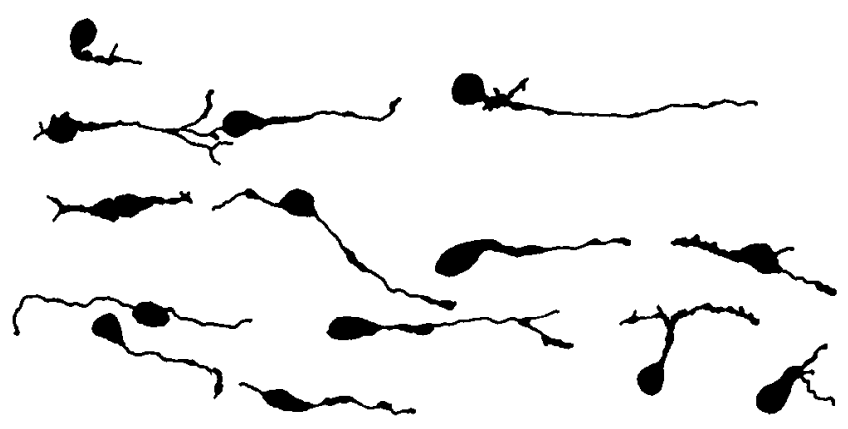

B $\quad$ P8

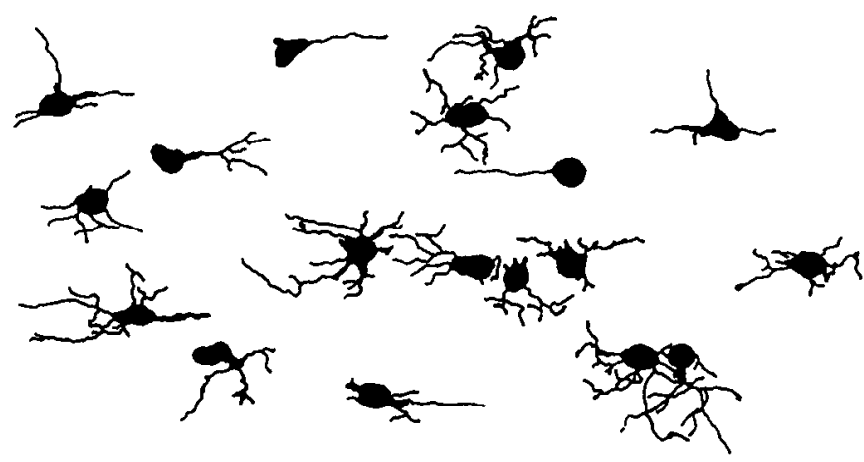

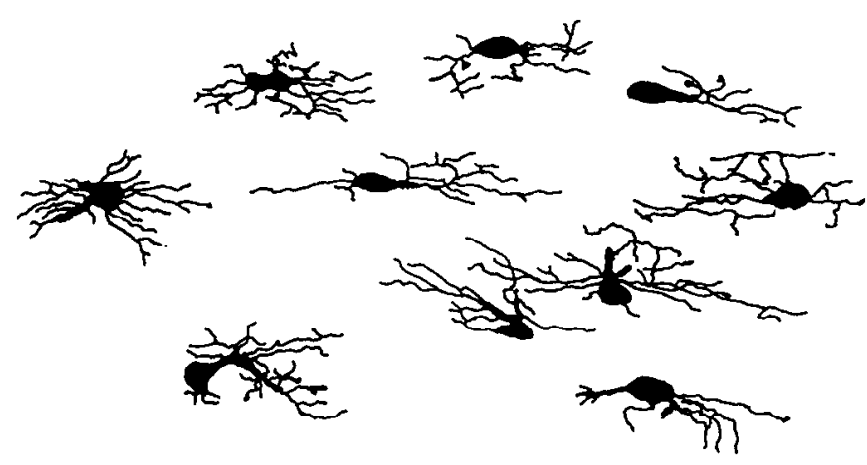

C

P20

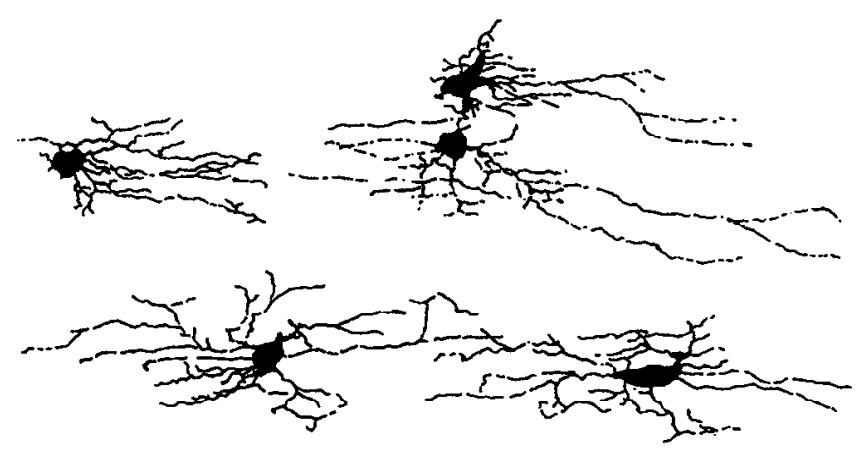

ADULT

Figure 3. Camera lucida drawings of cobalt-filled glial cells at different stages of development in whole-mounts of optic nerves treated with QUIS and cobalt. $A, \mathrm{P} 1 ; B, \mathrm{P} 8 ; C, \mathrm{P} 20 ; D$, Adult. Scale bar, $50 \mu \mathrm{m}$.

in the absence of cobalt and then washed before being exposed to cobalt, very few or no cobalt-filled glial cells were seen, suggesting that the cobalt uptake did not result from QUIS-induced cell damage. In perinatal nerves and some P8 nerves, cobalt uptake into glial cells showed a similar specificity throughout most of the nerve (Fig. $2 E$ ), but within the first $500 \mu \mathrm{m}$ of the retinal end of the nerve, a subpopulation of about 1500 glial cells with a predominantly transverse orientation contained cobalt following all of the treatments described above; thus, cobalt uptake in these cells did not require addition of QUIS and was not inhibited by CNQX. We did not study these cells further; counts of cobalt-filled cells made at these ages did not include this population (sce Matcrials and Mcthods) and all other analyses were made on cobalt-filled cells greater than $500 \mu \mathrm{m}$ distant from the retina. Thus, for the remainder of this article, the term "cobalt-filled glial cell" refers only to those glial cells that take up cobalt in the presence of QUIS via a CNQX-sensitive mechanism and all data presented relate to these cells.

The threshold concentration for detectable QUIS-induced cobalt uptake into glial cells in whole nerves was between 20 and $50 \mu \mathrm{M}$. At all ages, cobalt entry into glial cells was also stimulated by glutamate $(100 \mu \mathrm{M})$, kainate $(100 \mu \mathrm{M})$, and AMPA $(100 \mu \mathrm{M})$, but not by NMDA $(100 \mu \mathrm{m})$ or increased levels $(30 \mathrm{~mm})$ of extracellular potassium (not shown).

At all ages, a proportion of the axons in the nerve also contained cobalt, and in older nerves, some myelin sheaths did so as well. This labeling of axons and myelin sheaths is further described below.

\section{Characterization of cobalt-filled glial cells in intact optic nerve}

In whole-mounts and sections of treated nerves, the morphology, spatial distribution, and numbers of the cobalt-filled glial cells varied according to the age of the animal.

Morphology and orientation. The morphology of cobalt-filled glial cells increased dramatically in complexity during postnatal development (Figs. 2, 3). In nerves from neonatal animals (Figs. $2 A, 3 A$ ), filled cells had a simple unipolar or bipolar morphology, with primary processes that were up to $70 \mu \mathrm{m}$ long (mean length, $29.6 \pm 15.0 \mu \mathrm{m} ; n=35)$ and usually of large diameter (2-3 $\mu \mathrm{m})$, particularly over their proximal portion. These processes gave rise to few, if any, major branches, but somctimes a few short, fine processes projected from them along their length. The majority of cells were oriented longitudinally, with their primary processes running parallel to the axons. The cell bodies were oval (long diameter, $10.63 \pm 1.51 \mu \mathrm{m}$; short diameter, $5.88 \pm 0.95 \mu \mathrm{m}$; mean soma diameter, $8.26 \pm 0.72 \mu \mathrm{m} ; n=$ 17) and were usually oriented with their long diameter parallel to the main direction of the processes. At their tips, processes often forked into short branches or formed club-like expansions. Of 115 unipolar cells examined (in two nerves), 88 (77\%) had their single process directed toward the eye.

During early postnatal development, there was a gradual increase in the morphological complexity of cobalt-filled glial cells. At P7-8 (Figs. $2 B, 3 B$ ), $20-50 \%$ of these cells still retained a simple perinatal morphology, with one or two thick processes; although many of these were longitudinally oriented, some had 


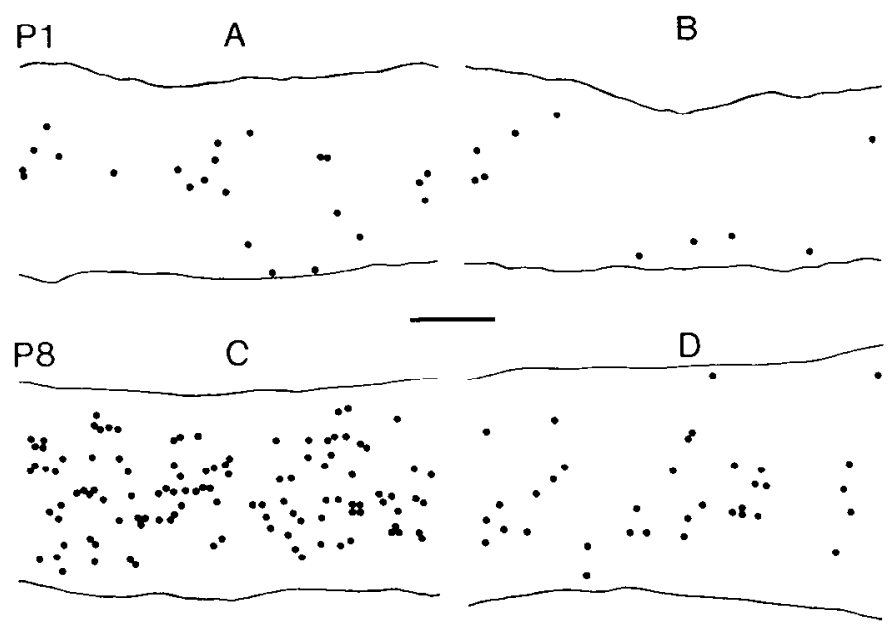

Figure 4. Distribution of cobalt-filled glial cells. $A$ and $B$, Camera lucida drawings of two regions of a $2 \mu \mathrm{m}$ longitudinal plastic section of a P1 optic nerve treated with QUIS and cobalt. The section in $A$ is from within $1 \mathrm{~mm}$ of the chiasm, while that in $B$ is from within the region $500 \mu \mathrm{m}$ to $1 \mathrm{~mm}$ from the eye. The dots indicate the location of cobaltfilled cell bodies. $C$ and $D$, As for $A$ and $B$, but from a P8 nerve. Scale bar, $100 \mu \mathrm{m}$.

a distinct transverse orientation. The majority of cells at this age, however, extended three to seven shorter $(5-30 \mu \mathrm{m})$ and finer processes that gave rise to a variable number of short, fine branches; most of these cells had no particular orientation, and their processes radiated out in all directions. Some cells had an intermediate morphology: they had one or two major thick processes but, in addition, had a few much shorter and finer processes arising from either the cell body or the proximal part of the major processes (Fig. $3 B$ ). The mean soma diameter of cobalt-filled cells was smaller at P8 than at P1 $(6.96 \pm 0.79 \mu \mathrm{m}$; $n=25$ ).

At the end of the third postnatal week (P18-P22), the majority of cobalt-filled glial cells had a complex morphology with fine, branching processes (Figs. $2 C, 3 C$ ); the mean soma diameter was $6.93 \mu \mathrm{m}( \pm 0.75 \mu \mathrm{m} ; n=20)$. A small proportion of cells $(<10 \%)$ were of simpler morphology, usually resembling the transitional morphology seen at P7-P8, rather than the perinatal morphology. In complex cells, the number of primary processes (three to seven) had not increased, but the processes were longer (up to $45 \mu \mathrm{m}$ ) than at P8, gave rise to more branches, and were predominantly longitudinally orientated, running among and parallel to the axons. Occasionally, primary processes were thick for the first $10-20 \mu \mathrm{m}$, but then branched to give rise to a number of finer processes (see Figs. $3 C, 6 A$ ). Sometimes these thick primary processes ran transversely, giving off finer longitudinal branches; glial cells with a similar morphology to this have been described in Golgi studies by Ramón-Moliner (1958). This complex morphology persisted in adult nerves, with an increase both in the maximum length of the processes (to about $100 \mu \mathrm{m}$ ) and in branching (Figs. $2 D, 3 D$ ); on average, adult cells make about 28 endings. The mean soma diameter of cobalt-filled cells in adult nerves was $6.87 \pm 1.03 \mu \mathrm{m}(n=21)$. In none of the adult nerves did we see any cells with the simple morphology characteristic of the perinatal cells. However, since cobalt-filled cells could be visualized only in the periphery of adult nerves, it is possible that similar cells located deeper in the nerve may have a different morphology.

Distribution. In neonatal animals (P0-P2), cobalt-filled glial cells were found throughout the thickness of the nerve (Figs. $2 A, 4 A, B)$. Within the core of the nerve (middle $50-70 \mu \mathrm{m}$ ), where large numbers of axons were filled with cobalt throughout their length, the cobalt-filled glial cells were often more intensely stained than those toward the periphery of the nerve. At this age, there was a rostrocaudal gradient in the occurrence of cobalt-filled glial cells, the mean density being two to three times higher within $1 \mathrm{~mm}$ of the chiasm (Fig. $4 A$ ) than within $1 \mathrm{~mm}$ of the eye (Fig. $4 B$ ); the total nerve length at this stage was approximately $3 \mathrm{~mm}$. Because of the occurrence of CNQXinsensitive cobalt-filled cells within $500 \mu \mathrm{m}$ of the eye, cell numbers for the eye end of the nerve were obtained between 500 $\mu \mathrm{m}$ and $1 \mathrm{~mm}$ from the eye. This rostrocaudal gradient was still apparent in some nerves at P8 (Fig. $4 C, D$ ), but by the end of the second week, cobalt-filled glial cells were generally uniformly distributed along the length of the nerve.

When whole optic nerves from animals aged P18-P35 were treated with QUIS and cobalt, the pattern of cobalt labeling varied greatly from nerve to nerve. Cobalt-filled glial cells were found either throughout the thickness of the nerve (Fig. $4 E$ ) or restricted to the periphery of the nerve, occurring only within $30-50 \mu \mathrm{m}$ of the pial surface; the mean density of cobalt-filled cells within this surface region was similar in both cases. We could not attribute success in obtaining cobalt-uptake in glial cells throughout the thickness of these older nerves to any obvious preparative procedure, such as careful removal of the meninges. In adult nerves, cobalt-filled glial cells were never seen to occur farther than $50 \mu \mathrm{m}$ from the pial surface and, in some cases, large patches of the nerve contained no cobalt-filled cells at all. The increase in variability of cobalt uptake by glial cells in older nerves suggests that, as the nerve matures, diffusion of reagents into the nerve from the pial surface becomes progressively restricted. Slitting the pial surface, hemisecting the nerve, or cutting it into small pieces to try to increase access to the interior of the nerve resulted in nonspecific cobalt uptake (i.e., uptake that was not inhibited by CNQX) into cells in the region adjacent to the cut.

In neonatal nerves, pairs of closely apposed cobalt-filled glial cells were occasionally seen (Fig. $4 A, B$ ). By the beginning of the second postnatal week (P7-P8), pairs and small clusters of three or four cobalt-filled cells were seen more frequently (Fig. $4 C, D$ ), and in nerves of P18 or older such clustering was common.

Number and density. Estimates of the total number of cobaltfilled glial cells per nerve made at different postnatal ages (see Materials and Methods) are plotted in Figure $5 \mathrm{~A}$. Since the rat optic nerve undergoes about a 12-fold increase in volume between birth and adulthood, we have also expressed these values as the mean number of cobalt-filled glial cells per unit volume $\left(10^{-3} \mathrm{~mm}^{3}\right.$, i.e., a cube with $100 \mu \mathrm{m}$ sides) of nerve (Fig. $5 A$ ). P1 optic nerves contained about 2700 cobalt filled glial cells (9\% of the estimated total glial cells in the nerve; Fig. $5 B$ ), with a mean density of 25 cells $/ 10^{-3} \mathrm{~mm}^{3}$. Between P1 and P14 there was an eightfold increase in the total number of cobalt-filled glial cells per nerve and a threefold increase in density of these cells; the mean density of cobalt-filled glial cells peaked at P14, when these cells constituted about $13 \%$ of the glial cells in the nerve. The total number of cobalt-filled cells remained relatively stable during the subsequent 2 weeks, with a concomitant decrease in density to approximately neonatal values by $\mathrm{P} 31$. The estimated cell numbers for P19 and P31 nerves (Fig. 5A) were obtained from nerves in which cobalt-filled cells were found throughout the tissue. 
In adult nerves, the total number of cobalt-filled cells fell to about $16,000(\approx 7 \%$ of total glial cells), with a mean density of 13 cells $/ 10^{-3} \mathrm{~mm}^{3}$, which is about half that seen in neonatal nerves and about one-fifth of the density during the second postnatal week. Since glial uptake of cobalt in adult nerves was always limited to the peripheral $50 \mu \mathrm{m}$ of the nerve, these estimates were obtained by extrapolation from counts of cobaltfilled cells within defined areas of this peripheral region, on the assumption that, under optimum conditions, cobalt-filled glial cells would be uniformly distributed throughout the adult nerve as they are in P14-P31 nerves. If cells that can be induced by QUIS to take up cobalt are really confined to the periphery of the adult nerve, which seems unlikely, our estimates would be two- to threefold too high.

\section{Electron microscopy of cobalt-filled glial cells in P18 optic nerve}

Four P18 nerves treated with QUIS and cobalt were examined at the EM level to determine the ultrastructure of the cobaltfilled cells, as well as their relationship to other cells and structures in the nerve. When examined as whole-mounts, nerves processed for EM containcd much less intense silver/cobalt deposits than those that had been processed for light microscopy, presumably as a result of osmication (Tyrer et al., 1980). Nonetheless, some cells retained enough silver-intensified cobalt to be detected at the EM level. Tissue preservation was not optimal for EM studies, partly because of the unphysiological conditions of the cobalt assay and partly because the nerves were subsequently fixed by immersion rather than by perfusion.

In nerves treated with QUIS and cobalt, a subpopulation of glial cells contained levels of cobalt that were much greater than the background levels seen in the surrounding tissue (Fig. 6A$D)$. As in the case of nerves processed for light microscopy, the omission of QUIS or the presence of CNQX largely eliminated the glial cell labeling (not shown). In all the QUIS/cobalt-treated nerves examined at the EM level, cobalt-filled cells were confined to the periphery of the nerve and were not found farther than $50 \mu \mathrm{m}$ from the pial surface, probably because of restricted diffusion of one or more of the reagents involved in the assay procedures (see above). Removal of the meninges did not significantly alter this distribution.

In QUIS/cobalt-treated nerves, cells that had the characteristic ultrastructural features of mature oligodendrocytes (Fig. $6 A, B$ ) or astrocytes (Fig. $6 A$ ) could be readily identified. In mature oligodendrocytes, both the cytoplasm and the nucleoplasm were more electron dense than in astrocytes. The nucleus of oligodendrocytes contained small, irregular clumps of chromatin, both beneath the nuclear membrane and throughout the nucleoplasm; the rough endoplasmic reticulum was often organized in stacks (Fig. 6B). In addition to being less electron dense, astrocytes were larger than oligodendrocytes and contained characteristic glial filaments (Fig. 6A). Neither of these cell types contained cobalt above background levels (Fig. 6A,B). The cclls that did contain significant amounts of cobalt generally all had a similar appearance (Fig. 6A-D). Their cytoplasm was less electron dense than that of mature oligodendrocytes, but was darker than that of mature astrocytes (Fig. $6 \mathrm{~A}$ ) and, except in regions where the cell body gave rise to processes, formed only a thin layer around the nucleus. The nucleoplasm was also intermediate in density between that of mature oligodendrocytes and astrocytes (Fig. 6A); it usually contained a prominent nucleolus (Fig. 6B) and clumped heterochromatin at the nuclear
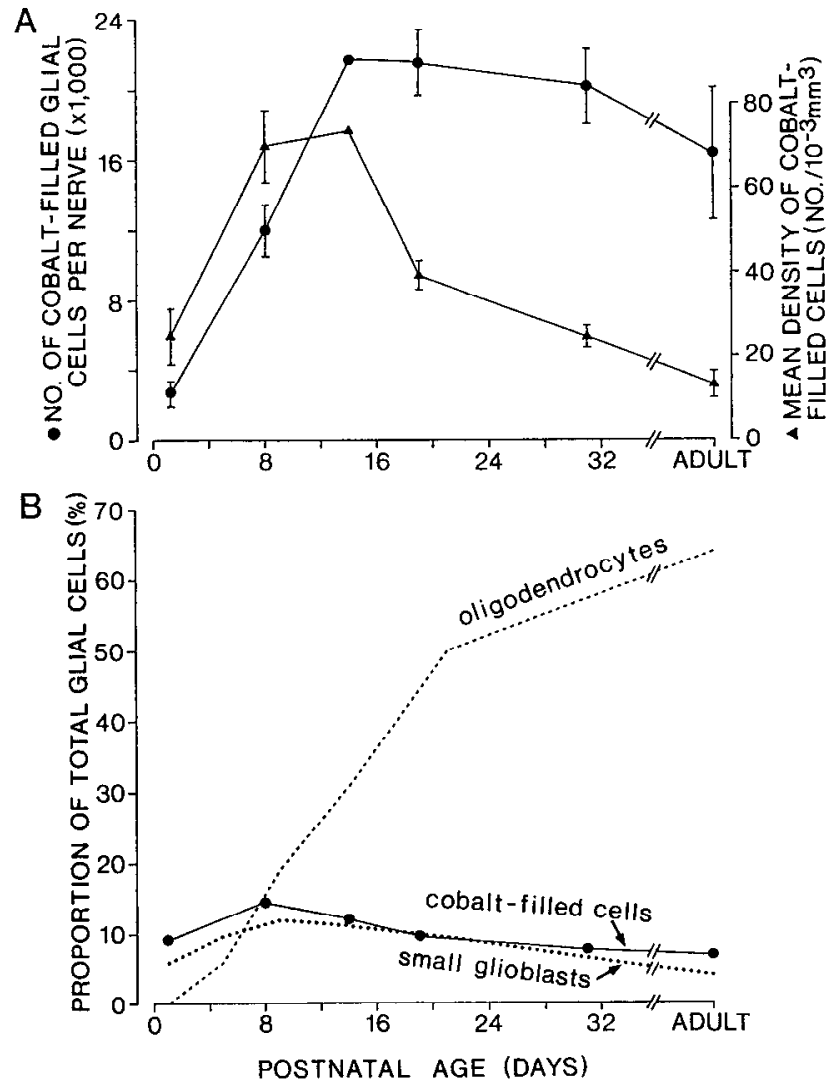

Figure 5. Total number, mean density, and proportion of cobalt-filled glial cells in optic nerves of different ages treated with QUIS and cobalt. $A$, The total number of cobalt-filled glial cells per optic nerve was estimated as described in Materials and Methods. At each age values were obtained from at least two different animals, except at P14, when only a single value was obtained. Mean values for each age are plotted as solid circles; error bars indicate SD. The mean density of cobalt-filled glial cells was calculated by dividing the number of such cells per nerve by the total volume of the nerve. These values are plotted as solid triangles; error bars indicate SD. $B$, The proportion of cobalt-filled glial cells (solid circles) was calculated as a pcreentage of the total number of glial cells per nerve estimated using the data of Vaughn (1969) (see Materials and Methods for details). For comparison, the proportions of cells designated by Vaughn (1969) as small glioblasts and oligodendrocytes have each been calculated as a percentage of the total number of glial cells per nerve and are represented by the dotted and dashed lines, respectively. The following dimensions (diameter/length in micrometers) have been used to calculate the total volume of optic nerves at different ages: P1, 215/2970; P8, 230/4136; P14, 270/5175; P19, 340/ 6055; P31, 380/7279; adult, 420/9000.

membrane. Careful examination of 20 such cells revealed no evidence of intermediate filaments or of any known characteristic features of differentiated glial cells. Cells with a similar characteristic appearance (but not containing cobalt) were seen in nerves treated with cobalt alone or with QUIS and cobalt in the presence of CNQX (not shown), or in perfusion-fixed nerves that had been subjected only to the silver intensification procedure (Fig. 7).

As was noted at the light microscope level, a thick process could be seen in some cases to arise from the cell body (Fig. $6 A$ ). Also, in the vicinity of the cobalt-filled cell bodies, and sometimes continuous with them, portions of very fine cobaltfilled processes were usually seen (Fig. 6A,C,D). In transverse sections (Fig. 6A), these processes were seen to be smaller in diameter than most of the axons. Many of these processes ran 

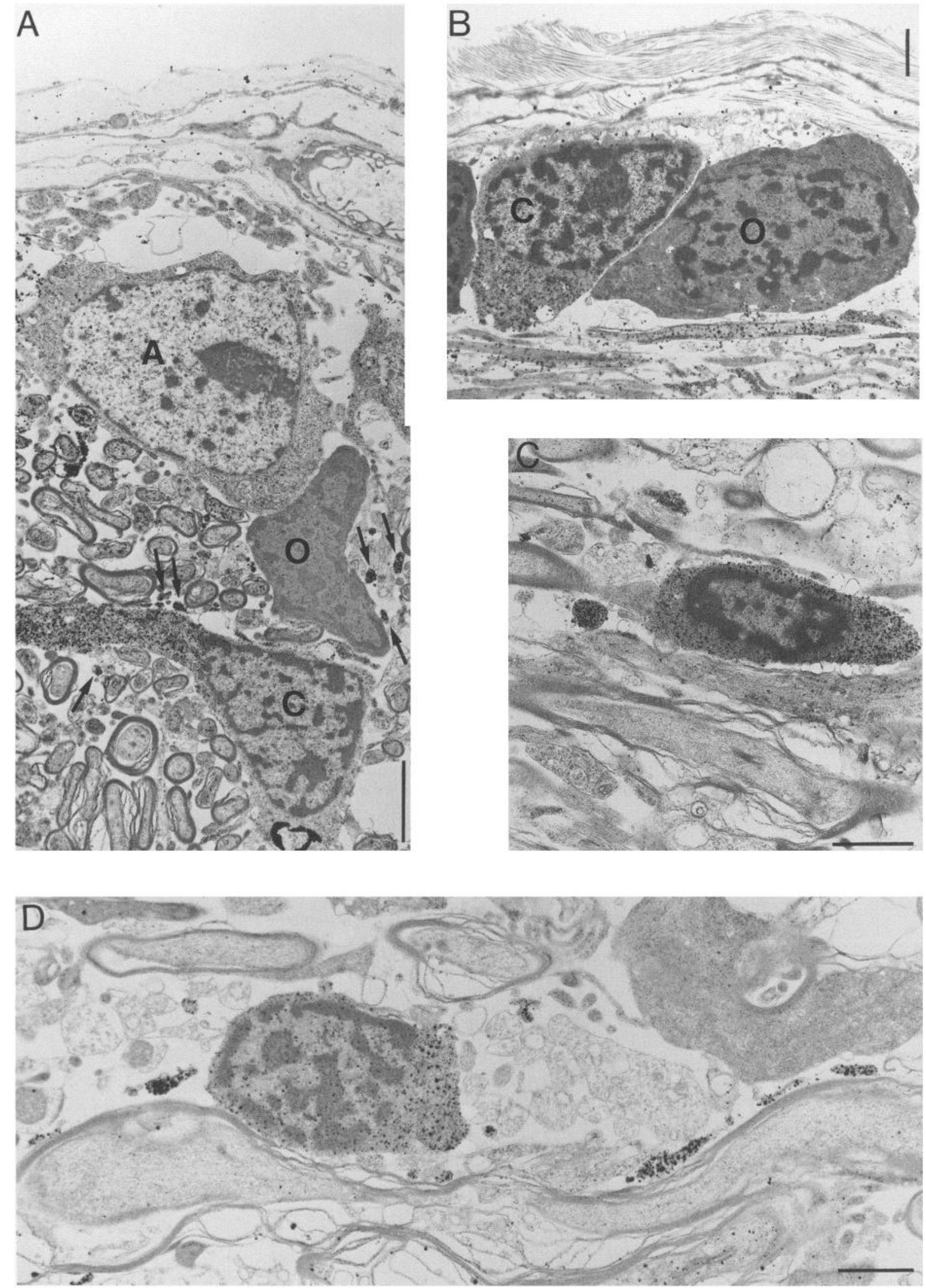

Figure 6. Electron micrographs of cobalt-filled glial cells in P18 optic nerves treated with QUIS and cobalt. A, Transverse section showing a cobalt-filled cell (labeled $C$ ). An astrocyte (labeled $A$ ) and an oligodendrocyte (labeled $O$ ), neither of which contain above-background levels of cobalt, are also shown. Both the cytoplasm and the nucleoplasm of the cobalt-filled cell are intermediate in electron density between those of the astrocyte and the oligodendrocyte. Cobalt can also be seen in some axons and in fine processes surrounding the cobalt-filled cell (arrows). $B$, Longitudinal section showing a cobalt-filled cell (labeled $C$ ) and an oligodendrocyte (labeled $O$ ) close to the pial surface. $C$ and $D$, Longitudinal sections of intrafascicular cobalt-filled cells, showing that both the soma and fine longitudinal processes can form close associations with myelin sheaths and astrocytic processes. Scale bars: $A-C, 2 \mu \mathrm{m} ; D, 1 \mu \mathrm{m}$. 


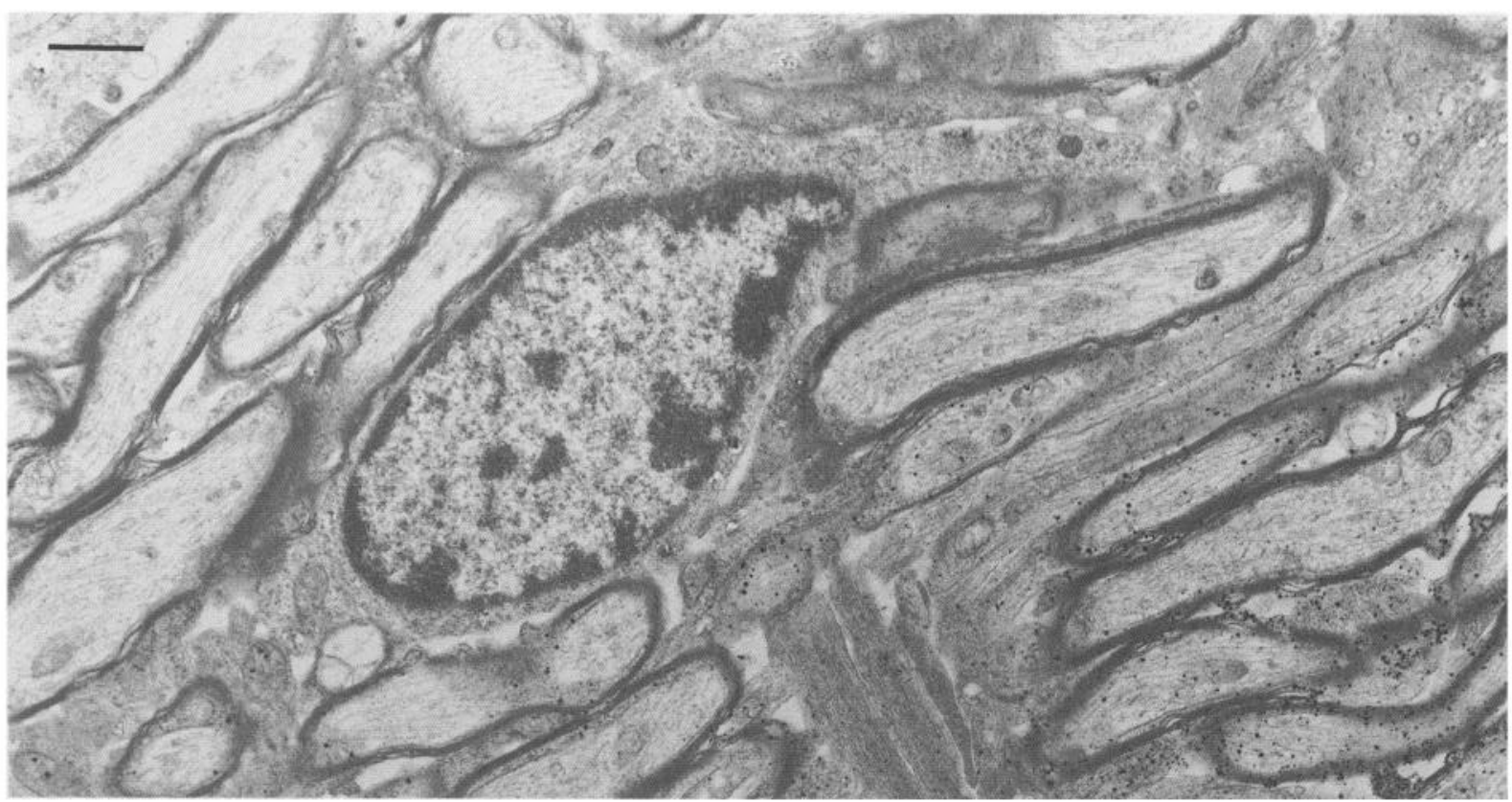

Figure 7. Longitudinal section of a P18 nerve that has been perfusion fixed and subjected to the silver intensification procedure only, showing that optic nerves that have not been exposed to cobalt and QUIS contain cells with similar ultrastructural characteristics as cobalt-filled cells. Only a low level of nonspecific silver staining can be seen. Scale bar, $1 \mu \mathrm{m}$.

within the bundles of axons and were sometimes seen to form a close association either with the surface of the myelin sheath (Fig. $6 D$ ) or with astrocyte processes (see also below).

\section{Cobalt uptake in axons and myelin sheaths}

During the first week of postnatal development, many axons, particularly in the core of the nerve, contained cobalt throughout their length (see Fig. $2 A, B$ ). This axonal uptake began to decrease toward the latter part of the second week, from which time it became progressively restricted to the nodes of Ranvier (Fig. $8 A, E)$. Cobalt uptake into axons also occurred in nerves exposed to cobalt without QUIS. To examine the possibility that the axonal uptake of cobalt might be mediated through the action of endogenous glutamate on axonal QUIS receptors, we incubated nerves in CNQX prior to, during, and after the addition of cobalt; axonal cobalt uptake still occurred under these conditions. The mechanisms underlying axonal and glial uptake of cobalt must therefore differ.

EM examination of axons in adult nerves treated with QUIS and cobalt (Fig. $8 E$ ) showed that the nodal region of the axon was intensely labeled with cobalt and that the density of cobalt in the axon decreased sharply with distance from the node, falling to insignificant levels within the paranodal region; cobalt was not found in axons farther than $2-3 \mu \mathrm{m}$ from the node. This pattern of cobalt labeling, combined with the fact that the axon has a greater diameter at the node than in the paranodal region, resulted in labeled nodes having a characteristic appearance when viewed by light microscopy (Fig. $8 A-D$ ); the variation in size of these structures, which is evident in Figure $8 A$, presumably reflects the variation in axon diameter in the rat optic nerve. Cobalt-filled nodes could be found throughout the length of adult nerves. This, combined with the pattern of labeling at the node, strongly suggests that cobalt entry into axons occurs via the axolemma, rather than via the cut ends. Interestingly, a similar intense labeling of nodes of Ranvier has been described in frog spinal cord following ionophoretic staining of axons from the proximal stump of transected dorsal roots via a suction electrode containing cobalt chloride (Llinás, 1973). In this situation, where the internodal axon was also weakly stained, it is unclear whether all axonal labeling occurs via the cut end or whether some cobalt diffuses into the cord and enters axons across the nodal axolemma, as suggested above.

From P14, cobalt could be detected in some myelin sheaths. Like axonal uptake of cobalt, myelin sheath labeling could also be seen following exposure to cobalt alone. The cobalt was usually confined to the paranodal region, but could occasionally be seen throughout an entire internode of the myelin sheath (Fig. $8 B$ ). Both in cobalt alone and in cobalt and QUIS, the uptake of cobalt into myelin sheaths was highly variable, making it difficult to assess whether it could be inhibited by preincubation in CNQX.

\section{Location and associations of cobalt-filled cells}

Light microscopic examination of cobalt-filled glial cells in sections showed that, at all ages, their cell bodies were located either within a bundle of axons, or within the longitudinal rows of glial cell somata that lie between axon bundles. In addition, the somata or processes of some cobalt-filled glial cells could be seen to lie close to either the pial surface or a blood vessel. In agreement with these observations, electron micrographs of P18 nerves showed that the somata of cobalt-filled cells were found either within longitudinally organized rows of unlabeled glial cell somata (see Fig. 6B) or in an intrafascicular location, away from other glial cell somata and closely associated with axons and/or astrocyte processes (see Fig. $6 C, D$ ). It is clear from Figure 6 that both the somata and processes of cobalt-filled glial cells can form close associations with the myelin sheaths surrounding the axons and also with both the somata and processes of other types of macroglial cells. As shown in Figure $6 B$, some cobalt-filled cells were located very close to the pial surface, but 

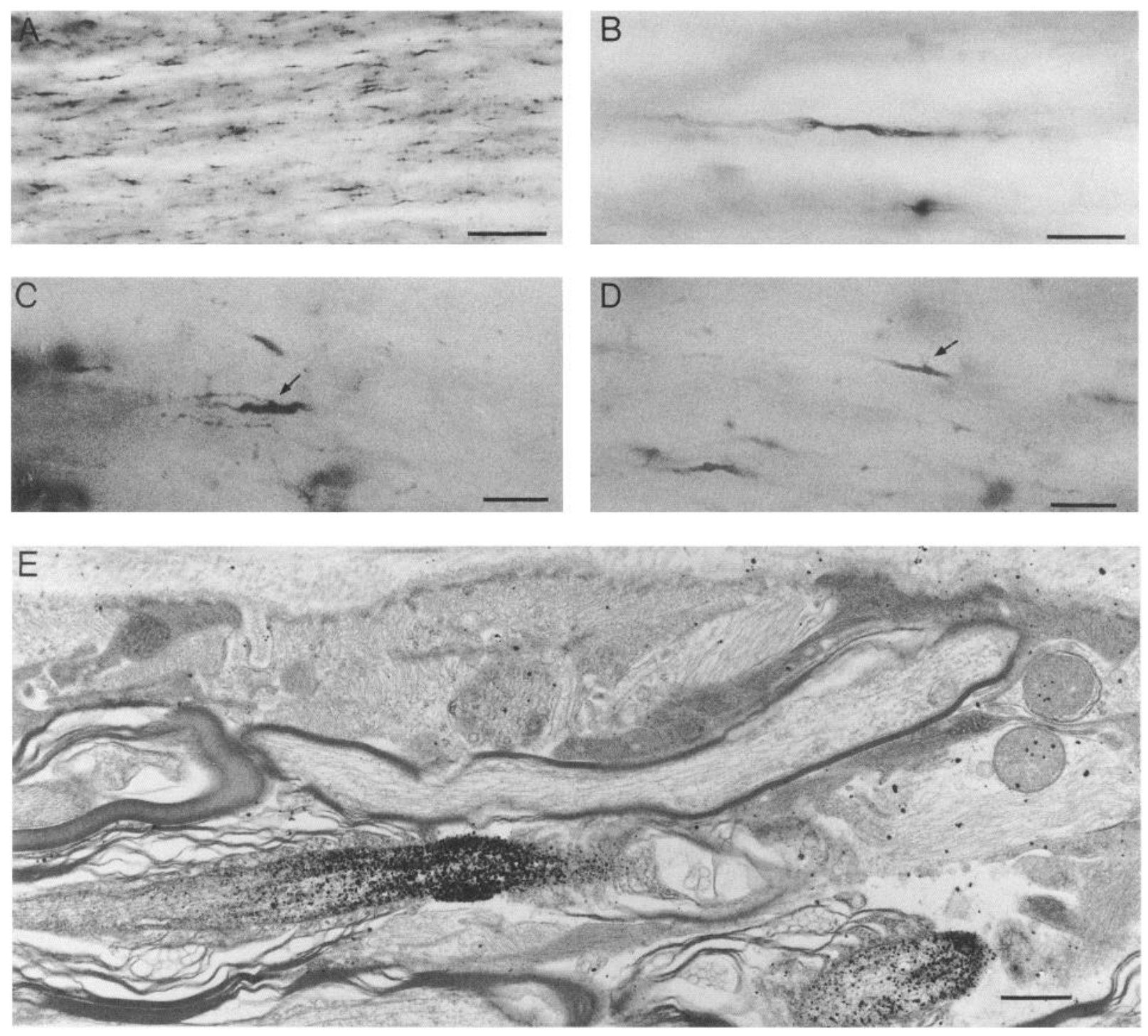

Figure 8. Non-QUIS-induced cobalt uptake into axons at nodes of Ranvier and into myelin sheaths. $A$, Whole-mount preparation of an adult optic nerve exposed to cobalt without QUIS. Cobalt is present in many axons, but only in the nodal and paranodal regions. Note the variety of sizes of the nodal profiles. $B$, Same nerve as in $A$. Cobalt is present not only in the axon, but also in the myelin sheath; in this example, cobalt was present throughout the length of several internodes of the myelin sheath. $C$, Whole-mount preparation of a P21 optic nerve treated with cobalt and QUIS. A longitudinal process of a cobalt-filled cell appears to contact an axon at the node of Ranvier. $D$, Whole-mount preparation of a P23 nerve exposed to cobalt without QUIS. Short, fine, cobalt-filled structures are associated with an axon at the node of Ranvier ( $C$ and $D$, arrows). $E$, Electron micrograph of an adult optic nerve treated with cobalt and QUIS. Intense cobalt staining can be seen at two nodes of Ranvier, and the density of cobalt declines within the paranodal region. No cobalt can be seen in the internodal stretches of axon. Scale bars: $A, 50 \mu \mathrm{m} ; B, 20 \mu \mathrm{m}$; $C$ and $D, 10 \mu \mathrm{m} ; E, 1 \mu \mathrm{m}$.

they were always separated from the pial basal lamina by fine astrocyte processes or end-feet. As with cell bodies, cobalt-filled processes sometimes ran extremely close to the pial surface, but astrocyte processes were always interposed (not shown). None of the 20 cobalt-filled glial cells examined electron microscopically was associated with blood vessels.

In older nerves, the processes of cobalt-filled glial cells were usually extremely fine (see Figs. $2 D, 3 D$ ) and did not always contain detectable levels of cobalt throughout their entire length. Consequently, it was often difficult to ascertain where these processes terminated. In some cases, however, it was clear from examination of whole-mount preparations that such processes ended near (see Fig. $8 C$ ), or passed very close to, nodes of Ranvier, which could be readily identified by the restricted uptake of cobalt in this region of the axon. In nerves treated with
QUIS and cobalt, fine processes of cobalt-filled cells formed close associations with about $10-15 \%$ of the cobalt-filled nodes of Ranvier. In addition, in nerves incubated in cobalt alone, short, fine, twig-like structures, a few micrometers in length, could sometimes be seen associated with the cobalt-filled nodes of Ranvier (see Fig. $8 D$ ). In view of their very small diameter, it seems unlikely that these structures were branches of the axon arising at the node, and likely that they were portions of glial processes associated with the nodal axon. In our limited EM study, however, we found no examples of cobalt-filled processes contacting nodes of Ranvier.

\section{QUIS-induced cobalt uptake in transected nerves}

During development, microglia, which are the resident macrophages of the CNS, undergo a change in morphology as they 

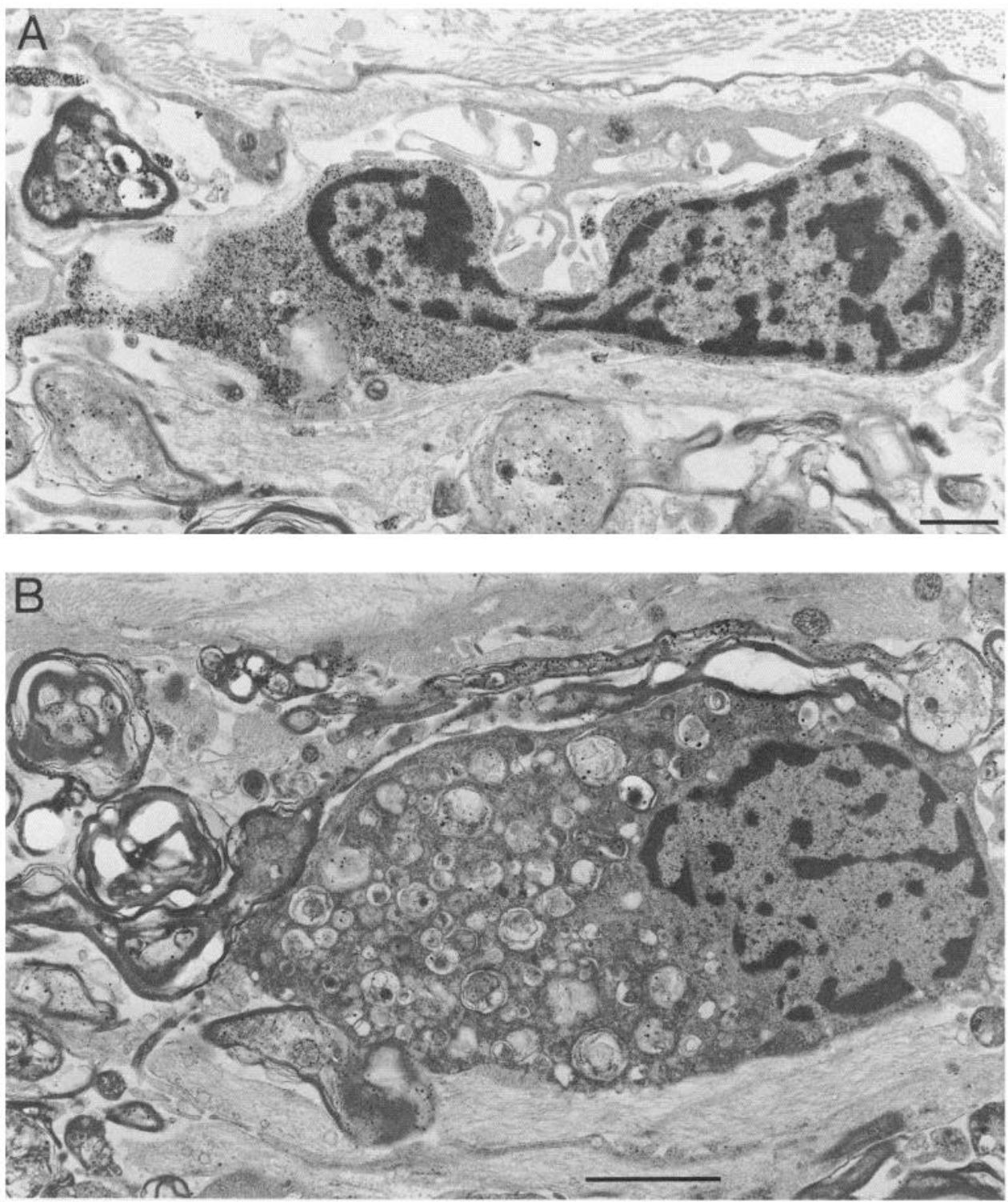

Figure 9. Electron micrographs of a cobalt-filled cell $(A)$ and a macrophage $(B)$ in a 7-week-old rat optic nerve treated with cobalt and QUIS 1 week after the nerve was transected behind the eye. Note that the cobalt-filled cell resembles those in unoperated nerves, and the macrophage does not contain abovebackground levels of cobalt. Scale bars: $A, 1 \mu \mathrm{m} ; B, 2 \mu \mathrm{m}$. differentiate from invading monocytes (Perry and Gordon, 1988). This change in morphology shares some similarities with the change from simple to complex morphology seen in cobalt-filled glial cells during early postnatal development of the optic nerve. Although microglial cells in vitro were not stimulated by QUIS to take up cobalt (see above), it was important to determine whether the cobalt-filled cells seen in QUIS-stimulated optic nerves might be microglia. We therefore looked at QUIS-stimulated cobalt uptake in optic nerves of 4-6 week old rats 1 week after the nerves were transected; the microglial cells in these nerves should have transformed into readily identifiable macrophages. In the light microscope, the morphology, density, and distribution of cobalt-filled glial cells in QUIS-treated transected nerves were not appreciably different from those in control nerves (not shown). EM examination of transected nerves showed that the abundant macrophages did not contain cobalt (Fig. 9B), while the cells that did contain cobalt had the same ultrastructural characteristics as those in control nerves (Fig. 9A).

\section{Discussion}

In this study we show that, at all stages of postnatal development, a substantial subpopulation of glial cells in the intact rat optic nerve can be stimulated by QUIS to take up extracellular cobalt. Following precipitation and silver intensification, the cobalt can be visualized in these cells in either whole-mounts or sections of the nerve. The cobalt-filled cells constitute $9 \%$ of the glial cells in the neonatal optic nerve, about $13 \%$ in the P14 nerve, and about $7 \%$ in the adult nerve. They initially have a simple unipolar or bipolar morphology that progressively increases in complexity during postnatal development. The cobalt uptake is also stimulated by glutamate, kainate, or AMPA, but not by NMDA, and it is inhibited by the glutamate antagonist CNQX, indicating that it depends on the activation of ionotropic glutamate receptors of the QUIS/AMPA type; this is in agreement with the findings of Pruss et al. (1991). It seems likely that cobalt enters the glial cells directly through the QUIS-gated 
channels, rather than secondarily through voltage-activated $\mathrm{Ca}^{2+}$ channels or as a result of injury, as no cobalt entry was induced by high levels of extracellular $\mathrm{K}^{+}$(see also Pruss et al., 1991) or when cobalt was applied after exposure to QUIS. A number of studies have now shown that some types of non-NMDA channels in the CNS are permeable to $\mathrm{Ca}^{2+}$ (Iino et al, 1990; Hollmann et al., 1991; see Pruss et al., 1991), including those in cultured cerebellar type 2 astrocytes, which have low permeability (Wyllie and Cull-Candy, 1992).

\section{The identity of the cobalt-filled glial cells}

Several lines of evidence suggest that the cells that take up cobalt in the optic nerve belong to the O-2A lineage, and are most likely the in vivo counterpart of $\mathrm{O}-2 \mathrm{~A}$ progenitor cells. First, patch-clamp studies have shown that, in vitro, $\mathrm{O}-2 \mathrm{~A}$ progenitor cells and type 2 astrocytes express QUIS/AMPA receptors while oligodendrocytes and type 1 astrocytes do not (Cull-Candy et al., 1989; Usowicz et al., 1989; Barres et al., 1990a,b; Wyllie et al., 1991). O-2A progenitors have also been shown to express these receptors in vivo, while oligodendrocytes and type 1 astrocytes do not (Barres et al., 1990a,b). In the initial description of excitatory amino acid-stimulated cobalt uptake, Pruss et al. (1991) provided evidence that both type 2 astrocytes and O-2A progenitors in rat cerebellar cultures take up cobalt in response to glutamate, QUIS, or AMPA while oligodendrocytes, type 1 astrocytes, fibroblasts, and meningeal cells do not. In this study we show that, in purified cultures of optic nerve glial cells, the only cell types stimulated by QUIS to take up detectable amounts of cobalt are O-2A progenitor cells and type 2 astrocytes; no uptake occurs in oligodendrocytes, type 1 astrocytes, or microglial cells.

A second line of evidence comes from the developmental changes in number and density of cobalt-filled glial cells (see Fig. 5), which are consistent with these cells being O-2A progenitor cells. Cobalt-filled cells are present in neonatal optic nerve and subsequently increase in frequency; both the total and the mean density peak at around 2 weeks after birth, which coincides with the peak period of oligodendrocyte production (Skoff et al., 1976). In addition, during the early stages of postnatal development, our estimates of the numbers of cobalt-filled glial cells per nerve are nearly identical to the numbers of $\mathrm{O}-2 \mathrm{~A}$ progenitor cells per nerve previously reported in cell suspensions of rat optic nerve (Miller et al., 1985; Small et al., 1987). In making this comparison, however, it should be borne in mind that it is not known what proportion of the total population of $\mathrm{O}-2 \mathrm{~A}$ progenitors is recovered from dissociated nerves, what proportion of cells that express QUIS receptors in the nerve take up sufficient cobalt to be detected, or how homogeneous $\mathrm{O}-2 \mathrm{~A}$ progenitor cells are in their properties. Although it is clear from our study that only about $25 \%$ of O-2A progenitor cells in vitro take up sufficient cobalt to be detected using the present methods of intensification, electrophysiological studies indicate that all $\mathrm{O}-2 \mathrm{~A}$ progenitor cells in vitro express QUIS receptors (Cull-Candy et al., 1989; Wyllie et al., 1991). The failure to label a proportion of these cells in culture, combined with the variation in the intensity of cobalt labcling obscrved, suggests that there might be substantial variability among these cells in the density (or cellular location) of QUIS receptors that they express. It is more difficult to deduce the extent of cobalt labeling of $\mathrm{O}-2 \mathrm{~A}$ progenitor cells in situ. As in culture, variation in the intensity of cobalt labeling in situ suggests variability in receptor density or location. Electrophysiological studies on cells in tissue prints of rat optic nerves, however, suggest that all O-2A progenitor cells have QUIS receptors, and that the density of these receptors may be substantially higher than in $\mathrm{O}-2 \mathrm{~A}$ progenitor cells in culture (Barres et al., 1990a). If this is so, then it is possible that most or all O-2A progenitor cells in situ are visualized in the cobalt assay. The recent findings of Pringle et al. (1992) provide strong support for this possibility. They used in situ hybridization to visualize cells in the rat optic nerve that express mRNA encoding PDGF $\alpha$-receptors, which seem to be expressed exclusively by $\mathrm{O}-2 \mathrm{~A}$ progenitor cells in the nerve. The numbers of cells that they detect in this way are almost identical to the numbers of cobalt-filled cells that we find at the same ages-P8, P14, and adult: whereas our estimates are 12,000, 22,000 , and 16,000 at these ages, theirs are $12,000,22,000$, and 18,000 .

A third line of evidence that cobalt-filled glial cells in the developing optic nerve are $\mathrm{O}-2 \mathrm{~A}$ progenitor cells is the graded distribution of the cobalt-filled cells along the length of the nerve in the first postnatal week, with a two to three times higher concentration at the chiasm end than at the eye end. A similar gradient was previously found when $\mathrm{O}-2 \mathrm{~A}$ progenitor cells were dissociated from different regions of perinatal rat optic nerve, and it was interpreted to suggest that these cells migrate into the developing optic nerve (Small et al., 1987). A similar gradient is also detected when PDGF $\alpha$-receptor mRNA is used to visualize O-2A progenitor cells in neonatal rat optic nerve (Pringle et al., 1992). O-2A progenitor cells have been shown to migrate rapidly in culture, in the direction of a long leading process (Small et al., 1987); our finding that $77 \%$ of the cobaltfilled cells with a unipolar morphology in neonatal nerves had their single process directed toward the eye provides strong support for the notion that progenitor cells migrate down the developing optic nerve toward the eye.

O-2A progenitor cells have been shown to be present in adult as well as immature rat optic nerve (ffrench-Constant and Raff, 1986a; Wolswijk and Noble, 1989), although the adult cells differ from the perinatal cells in many of their properties, including morphology, antigenic phenotype, cell cycle time, migration rate, and differentiation rate (Wolswijk and Noble, 1989). Time-lapse cinematographic studics suggest that the adult $\mathrm{O}-2 \mathrm{~A}$ progenitor cells develop from perinatal ones (Noble et al., 1989); the adult form first appears at about P7 and gradually increases to become the dominant form by about 1 month after birth (Wolswijk et al., 1990; Wren et al., 1992). While we do not know the antigenic phenotype, cell cycle time, or migratory properties of the cobalt-filled glial cells, the observed change in morphology of these cells over the first few weeks of postnatal development is consistent with the time course of the perinatalto-adult transition in the $\mathrm{O}-2 \mathrm{~A}$ progenitor population (Wren et al., 1992). Finally, cobalt-filled glial cells in P18 optic nerves appear to have similar ultrastructural characteristics to adult O-2A progenitor cells in culture (see Wolswijk et al., 1991).

Are any of the cobalt-filled cells astrocytes or oligodendrocytes? Since optic nerve O-2A progenitor cells have not previously becn charactcrizcd in situ, wc have no direct knowledge of their morphological or ultrastructural characteristics. The cobalt-filled glial cells have a number of morphological features, however, that distinguish them from mature astrocytes or oligodendrocytes. Moreover, they do not resemble any of the macroglial cell types that we or others have described in intracellular dyeinjection studies of developing or mature rat optic nerve. Such 
studies have shown two distinct macroglial cell types with a longitudinal orientation, both of which can first be recognized toward the end of the second postnatal week: one of these is the myelinating oligodendrocyte (Butt and Ransom, 1989; Ransom et al., 1991; B. P. Fulton, J. F. Burne, and M. C. Raff, unpublished observations), and the other has been classified as an astrocyte-like cell (Miller et al., 1989; see Fulton et al., 1991). Examples of these are shown in Figure 2, $G$ and $H$, on the same scale as the cobalt-filled cells shown in Figure $2 A-D$ for direct comparison.

Type 2 astrocytes in vitro have been shown to have QUIS receptors (Cull-Candy et al., 1989; Usowicz ct al., 1989; Barres et al., 1990a; Wyllie et al., 1991), and in this study we have shown that about $20 \%$ of type 2 astrocytes in culture are stimulated by QUIS to take up cobalt. None of the cobalt-filled cells examined by EM, however, have any of the characteristic features of astrocytes. We found no evidence of glial filaments in these cells, and no evidence that their processes make direct contact with either the pial surface or blood vessels. As we examined only 20 cobalt-filled cells by EM, however, we cannot rule out the possibility that a small percentage of cobalt-filled cells might possess astrocytic characteristics; fewer than $1 \%$ of O-2A lineage cells in 2-3 week old rat optic nerve are GFAP+ (Barres and Raff, unpublished observations). In previous studies (ffrench-Constant and Raff, 1986b; Miller et al., 1989), we have suggested that the in vivo counterpart of the type 2 astrocyte in vitro may be a cell that forms close associations with nodes of Ranvier, just as somc cobalt-filled cells were seen to do in this study. The somata of cobalt-filled cells, however, are significantly smaller, and the processes much finer, than those of astrocyte-like cells with a similar orientation visualized by intracellular injection of HRP (Fig. 2G; Miller et al., 1989). It is possible that some of the cells that were previously seen to be associated with nodes of Ranvier in sections of rat optic nerve and were suggested to be type 2 astrocytes may, in fact, have been O-2A progenitor cells (see below).

Although some of the cobalt-filled cells in the optic nerve, when viewed at the light microscopic level, bear some resemblance to myelinating oligodendrocytes in that both have arrays of parallel processes, the cell bodies of cobalt-filled cells are generally much smaller than those of oligodendrocytes visualized by injection of HRP (see Fig. $2 H$ ). The branching pattern of the processes of cobalt-filled cells, as well as the lengths of the primary processes, also differ from those of myelinating oligodendrocytes. Moreover, patch-clamp studies of oligodendrocytes in vitro ( $\mathrm{P} 1+3-4 \mathrm{~d}$ in vitro) suggest that they do not express QUIS receptors (Wyllie et al., 1991), and in this study, we could not detect significant QUIS-stimulated cobalt uptake in oligodendrocytes in culture ( $\mathrm{P} 7+2-3 \mathrm{~d}$ in vitro). Since oligodendrocyte precursor cells (O-2A progenitor cells) express QUIS receptors, however, newly formed oligodendrocytes might also do so. The morphology of newly formed oligodendrocytes in situ is not known, but would presumably be intermediate between myelinating oligodendrocytes and O-2A progenitor cells. It is, therefore, possible that a proportion of the cobalt-filled cells that we visualize in situ are newly formed oligodendrocytes; this proportion would be expected to increase during the first 2 weeks postnatally as oligodendrocyte production increases.

In nerves treated with QUIS and cobalt, or cobalt alone, cobalt can be seen in the myelin sheath, particularly in the paranodal region (see Fig. $8 B$ ), even though no glial cell bodies take up cobalt with the latter treatment. The presence of cobalt in the cytoplasm of the paranodal loops of some oligodendrocytes was confirmed by EM. It remains unclear whether cobalt uptake into the myelin sheath can be inhibited by CNQX and, thus, whether myelinating oligodendrocytes express QUIS receptors in the membrane that forms the myelin sheath.

\section{Associations of cobalt-filled glial cells}

We have not carried out a comprehensive study of the associations between cobalt-filled glial cells and other cells and structures in the nerve. From our light microscope studies, it appears that both the somata and the processes of cobalt-filled cells can lie close to the pial surface or blood vessels. The pial localization was confirmed by EM, but in all of the examples seen, astrocyte processes were interposed between the cobalt-filled cell and the pial basal lamina. Blood vessel associations were not seen in the limited EM analysis. There seems little doubt from examination of whole-mounts that the processes of at least some cobalt-filled cells either contact, or run very close to, axons at nodes of Ranvier; the exact nature of these nodal associations, however, remains uncertain. Some of the somata and processes of cobalt-filled cells contacted the somata or processes of astrocytes, or oligodendrocyte somata, or myelin sheaths.

\section{Relationship of cobalt-filled glial cells to previously described} glial cell types

The cobalt-filled glial cells in optic nerve resemble some other glial cell types, of uncertain identity, previously described in immunohistochemical and EM studies of optic nerve and other regions of the rat CNS. Some of the characteristics of these enigmatic cells are compared in Table 2. Ultrastructurally, cobalt-filled glial cells closely resemble cells previously described in the rat optic nerve, initially called a third neuroglial cell (Vaughn and Peters, 1968) and later referred to as a small glioblast (Vaughn, 1969). As shown in Figure $5 B$, the numbers of cobalt-filled glial cells at different stages of postnatal development closely parallel the numbers of small glioblasts reported by Vaughn (1969). Vaughn and his colleagues considered these cells to be both macroglial precursors and a source of macrophages in transected optic nerves (Skoff and Vaughn, 1971). The cobalt-filled cells in optic nerves are unlikely to be microglial cells, as microglial cells in culture do not take up cobalt in response to QUIS, and patch-clamp studies suggest that microglial cells do not have QUIS receptors (H. Kettenmann, personal communication). The cobalt-filled cells are also unlikely to be a source of macrophages: in transected optic nerves the macrophages do not take up cobalt, the number of cobalt-filled cells does not increase, and the morphology of cobalt-filled cells does not change. It seems likely that Vaughn's small glioblasts are the same as the cobalt-filled cells and adult $\mathrm{O}-2 \mathrm{~A}$ progenitor cells.

Cobalt-filled glial cclls also bcar some ultrastructural similarities to radiosensitive, slowly proliferating cells in the grey matter of the rat cerebral cortex, initially termed beta astrocytes (Reyners et al., 1982) and later reclassified as glial precursor cells (Reyners et al., 1986). Like cobalt-filled glial cells, these cells do not possess glial filaments and have only a thin layer of cytoplasm surrounding the nucleus; they do not make direct contact with basal lamina of blood vessels. Unlike cobalt-filled glial cells in the optic nerve, however, their processes are described as "scarce and retracted from other structures," but differences in the behavior of processes could reflect the different locations in the CNS. 
Table 2. Properties of some enigmatic glial cell types in rat CNS that do not have the characteristies typical of astrocytes or oligodendrocytes

\begin{tabular}{|c|c|c|c|c|}
\hline & $\begin{array}{l}\text { Third neuroglial } \\
\text { cell (small } \\
\text { glioblast) }\end{array}$ & $\begin{array}{l}\text { Beta astrocyte } \\
\text { (glial progenitor) }\end{array}$ & $\begin{array}{l}\text { Smooth } \\
\text { protoplasmic } \\
\text { astrocyte }\end{array}$ & $\begin{array}{l}\text { Cobalt-filled } \\
\text { glial cell }\end{array}$ \\
\hline Location & Optic nerve & Cerebral cortex & Cerebellar cortex & Optic nerve \\
\hline $\begin{array}{l}\text { Developmental } \\
\text { stage }\end{array}$ & $\begin{array}{l}\text { Developing + } \\
\text { adult }\end{array}$ & Adult & $\begin{array}{l}\text { Developing }+ \\
\text { adult }\end{array}$ & $\begin{array}{l}\text { Developing + } \\
\text { adult }\end{array}$ \\
\hline $\begin{array}{l}\text { Proportion of total } \\
\text { glial cells (in } \\
\text { adult) }\end{array}$ & $3-6 \%$ & $\approx 13 \%$ & $?$ & $7 \%$ \\
\hline $\begin{array}{l}\text { Antigenic } \\
\text { phenotype }\end{array}$ & $?$ & $?$ & $\begin{array}{l}\mathrm{NG}^{+} \\
\mathrm{GFAP}^{-} \\
\text {Vimentin }^{-}\end{array}$ & $?$ \\
\hline Shape & $?$ & Few processes & Stellate & $\begin{array}{c}\text { Longitudinal } \\
\text { processes }\end{array}$ \\
\hline $\begin{array}{l}\text { Associations of } \\
\text { processes }\end{array}$ & $?$ & $\begin{array}{l}\text { Retracted from } \\
\text { other structures }\end{array}$ & $\begin{array}{l}\text { Pial surface } \\
\text { blood vessels }\end{array}$ & Nodes of Ranvier \\
\hline Proliferation & $?$ & Yes & $?$ & $?$ \\
\hline References & $\begin{array}{l}\text { Vaughn and } \\
\text { Peters (1968) } \\
\text { Vaughn (1969) }\end{array}$ & $\begin{array}{l}\text { Reyners et al. } \\
\quad(1982,1986)\end{array}$ & $\begin{array}{l}\text { Levine and Card } \\
\qquad(1987)\end{array}$ & Present results \\
\hline
\end{tabular}

Levine and Card (1987) have described a population of glial cells in the rat cerebellar cortex that seem very likely to be closely related to the cobalt-filled cells and adult O-2A progenitor cells in optic nerve, even though these authors called the cells smooth protoplasmic astrocytes. These cells do not have intermediate filaments, but could be seen by light microscopy to contact blood vessels and the pial surface. Like cobalt-filled cells, their nucleus is surrounded by only a thin rim of cytoplasm. They express the NG2 chondroitin-sulfate proteoglycan on their surface, as do O-2A progenitor cells in cultures of optic nerve (Stallcup and Beasley, 1987) and cerebellum (Levine and Stallcup, 1987). Although their stellate morphology differs from the morphology of cobalt-filled glial cells in optic nerve, this could reflect environmental differences. Interestingly, Pruss et al. (1991) saw cobalt-filled stellate cells in cerebellar slices incubated in glutamate agonists, but their identity was uncertain.

The existence of glial cells with a morphology that is intermediate between oligodendrocytes and astrocytes has been debated in the literature for many years (see Ramón-Moliner, 1958). In many respects, the cobalt-filled cells could be described as such, raising the possibility that some of the cells previously placed in this category might be O-2A progenitor cells.

In the rat cerebellum (Curtis et al., 1987; LeVine and Goldman, 1988a; Reynolds and Wilkin, 1988) and forebrain (LeVine and Goldman, 1988b; Hardy and Reynolds, 1991), immunohistochemical techniques have been used to characterize and follow the development of oligodendrocyte precursor cells in situ. These studies have used a monoclonal antibody $\mathrm{LB}_{1}$, which binds to the $G_{\mathrm{D} 3}$ ganglioside that is expressed by immature neuroectodermal cells and glial progenitor cells similar to the $\mathrm{O}-2 \mathrm{~A}$ progenitor cells of the optic nerve in vitro (Curtis et al., 1987). The cells identified using this method bear some morphological and ultrastructural similarities to the cobalt-filled cells of the optic nerve.

\section{Are there type 2 astrocytes in the optic nerve?}

There is increasing evidence that if type 2 astrocytes are present in the rat optic nerve, they are likely to be a very minor subpopulation of the astrocytes in the nerve. First, very few cells with the antigenic phenotype characteristic of type 2 astrocytes in vitro are found in cell suspensions (Miller et al., 1985) or tissue prints (Barres et al., 1990b) of optic nerve. Second, only one of hundreds of cells with the morphology of astrocytes in tissue prints of optic nerve have the ion channel phenotype of type 2 astrocytes in culture (Barres et al., 1990b). Third, very few cells with the ultrastructural characteristics of astrocytes are produced in the optic nerve from dividing cells after the second postnatal week (Skoff, 1990), when most type 2 astrocyte development is thought to occur. Our failure to find astrocyte-like cells among the population of cobalt-filled cells in the optic nerve at any age provides a fourth line of evidence that very few, if any, O-2A progenitor cells in the optic nerve in vivo develop into cells with the properties of type 2 astrocytes in culture. Although all of the signals required to induce $\mathrm{O}-2 \mathrm{~A}$ progenitor cells to differentiate into type 2 astrocytes in culture are present in the optic nerve (Lillien and Raff, 1990), it seems that the great majority of progenitor cells either are not normally exposed to these signals or are unable to respond to them. One of the signals, ciliary neurotrophic factor (CNTF), does not contain a signal sequence characteristic of secreted proteins (Lin et al., 1989; Stöckli et al., 1991), and thus might not be released by the cells (type 1 astrocytes) that produce it unless the cells are injured (Lillien et al., 1988). There is evidence that CNTF functions as a Schwann cell-derived "lesion factor" in peripheral nerves to keep motoneurons alive after injury until their axons can grow back to their muscle targets (Sendtner et al., 1990). It is possible, therefore, that CNTF also functions as a lesion factor in the CNS, but if it does, it is unclear why O-2A progenitor 
cells should respond to it by expressing GFAP, or why its mRNA should be expressed in much higher levels in the optic nerve and olfactory bulb than elsewhere in the CNS (Stöckli et al., 1991).

ffrench-Constant and his colleagues (ffrench-Constant and Raff, 1986b; french-Constant et al., 1986) found that a number of antibodies, including the HNK-1 monoclonal antibody (Abo and Balch, 1981), that stain O-2A lineage cells in optic nerve cultures and label the J1 160 and J1 180 glycoproteins (Kruse et al., 1985) on immunoblots of optic nerve extracts also stained $\mathrm{GFAP}^{+}$elements surrounding nodes of Ranvier (perinodal astrocyte processes; Hildebrand, 1971), as well as fine longitudinal glial processes. Although it was proposed that both the perinodal HNK-1 ${ }^{+}$, GFAP $^{+}$processes and the fine longitudinal processes might come from type 2 astrocytes (ffrench-Constant and Raff, $1986 \mathrm{~b}$ ), it now seems possible that at least some of the HNK$1^{+}$glial processes come from $\mathrm{O}-2 \mathrm{~A}$ progenitor cells, as some fine, longitudinal cobalt-filled processes were seen in the present study to be associated with nodes of Ranvier. In addition, as $\mathrm{J} 1160$ and $\mathrm{J} 1180$ are also produced and secreted by oligodendrocytes in culture (Pesheva et al., 1989), it is possible that these glycoproteins at nodes of Ranvier are secreted locally by oligodendrocytes and/or O-2A progenitor cells and adhere to perinodal astrocyte processes, at least some of which come from type 1 astrocytes (Suárez and Raff, 1989).

The complex type of cobalt-filled glial cell in older optic nerves has a number of properties that were originally thought to be characteristic of type 2 astrocytes in vivo: they have fine longitudinally oriented processes that might contact nodes of Ranvier, and they begin to develop from perinatal O-2A progenitor cells beginning in the second postnatal week. The main difference is that they lack intermediate filaments and GFAP. It is possible, therefore, that our long and frustrating hunt for type 2 astrocytes in vivo has been misdirected by focusing on GFAP+ cells with a typical astrocyte morphology: these properties might be induced in vitro in O-2A progenitor cells by the release of CNTF from dying type 1 astrocytes in the cultures (see Lillien and Raff, 1990).

\section{What is the function of the complex cobalt-filled cells in the adult optic nerve?}

For reasons discussed above, we think it likely that the cobaltfilled glial cells in the adult optic nerve are the same as adult $\mathrm{O}-2 \mathrm{~A}$ progenitor cells that can be dissociated from the nerve in small numbers (less than 750 cells per nerve) (ffrench-Constant and Raff, 1986a; Wolswijk and Noble, in press). The latter cells are called $\mathrm{O}-2 \mathrm{~A}$ progenitor cells because, like their perinatal counterparts, they can differentiate into either oligodendrocytes or type 2 astrocytes in vitro, depending on the culture conditions, and it has been assumed that their primary function is to generate new glial cells to replace those that die, thereby mediating a slow turnover of these cells (ffrench-Constant and Raff, 1986a; Wolswijk and Noble, 1989). There are, however, reasons for reconsidering this assumption. If the cells function solely as oligodendrocyte precursors, why should they have such a complex morphology, express glutamate-gated cation channels, and extend processes to nodes of Ranvier? And why, given that oligodendrocyte turnover is thought to be very slow (McCarthy and Leblond, 1988), should they be so numerous, making up more than $5 \%$ of the glial cells in the optic nerve? In a recent study that compared the ability of $\mathrm{GC}^{+}$oligodendrocytes and $\mathrm{GC}^{-}$cells (including O-2A progenitor cells) isolated from the adult spinal cord to remyelinate axons of dorsal root ganglion neurons in culture, it was found that the $\mathrm{GC}^{+}$oligodendrocytes were more effective (Wood and Bunge, 1991). Finally, it seems likely that the $\mathrm{NG} 2+$ glial cells in the cerebellar cortex are equivalent to adult $\mathrm{O}-2 \mathrm{~A}$ progenitor cells; if their function is mainly to generate new oligodendrocytes, why are they in the molecular layer of the cerebellar cortex, which is largely devoid of oligodendrocytes and myelin, and why do they extend processes to blood vessels and to the pial surface (Levine and Card, 1987)?

If O-2A progenitor cells do not normally utilize their potential to differentiate into astrocytes in vivo, then they are inappropriately named. Until we know more about their function in the normal and injured adult CNS, however, it might be wise to postpone a rechristening. Future studies aimed at determining the functions of $\mathrm{O}-2 \mathrm{~A}$ progenitor cells will depend crucially on the ability to identify these cells in situ. We have shown that QUIS-stimulated cobalt-uptake provides a simple method for visualizing these cells both in the light and electron microscope. When used in combination with other techniques, it should prove a useful tool for investigating these enigmatic cells.

\section{References}

Abercrombie M (1946) Estimation of nuclear population from microtome sections. Anat Rec 94:239-247.

Abo T, Balch CM (1981) A differentiation antigen of human NK and $\mathrm{K}$ cells identified by a monoclonal antibody (HNK-1). J Immunol 127:1024-1029.

Ascher P, Nowak L (1987) Electrophysiological studies of NMDA receptors. Trends Neurosci 10:284-288.

Barres BA, Koroshetz WJ, Swartz KJ, Chun LLY, Corey DP (1990a) Ion channel expression by white matter glia. The O-2A progenitor cell. Neuron 4:507-524.

Barres BA, Koroshetz WJ, Chun LLY, Corey DP (1990b) Ion channel expression by white matter glia. The type-1 astrocyte. Neuron 5:527544.

Bartlctt PF, Noblc M, Pruss RM, Raff MC, Williams CA (1981) Rat neural antigen-2 (Ran-2): a cell surface antigen on astrocytes, ependymal cells, Müller cells and leptomeninges defined by a monoclonal antibody. Brain Res 204:339-351.

Bögler O, Wren D, Barnett SC, Land H, Noble M (1990) Cooperation between two growth factors promotes extended self-renewal and inhibits differentiation of O-2A progenitor cells. Proc Natl Acad Sci USA 87:6368-6372.

Bottenstein JE, Sato GH (1979) Growth of a rat neuroblastoma cell line in serum-free supplemented medium. Proc Natl Acad Sci USA 76:514-517.

Butt AM, Ransom BR (1989) Visualization of oligodendrocytes and astrocytes in the intact rat optic nerve by intracellular injection of Lucifer yellow and horseradish peroxidase. Glia 2:470-475.

Cull-Candy SG, Mathie A, Symonds CJ, Wyllie DJA (1989) Distribution of quisqualate and kainate receptors in rat type- 2 astrocytes and their progenitor cells in culture. J Physiol (Lond) 418:195P.

Curtis R, Cohen J, Fok-Seang J, Hanley MR, Gregson NA, Reynolds RA, Wilkin GP (1987) Development of macroglial cells in rat cerebellum. I. Use of antibodies to follow early in vivo development and migration of oligodendrocytes. J Neurocytol 17:43-54.

Davis NT (1982) Improved methods for cobalt filling and silver intensification of insect motor neurons. Stain Technol 57:239-244.

Eisenbarth GS, Walsh FS, Nirenberg M (1979) Monoclonal antibody to a plasma membrane antigen of neurons. Proc Natl Acad Sci USA 76:4913-4917.

ffrench-Constant C, Raff MC (1986a) Proliferating bipotential glial progenitor cells in adult rat optic nerve. Nature 319:499-502.

ffrench-Constant C, Raff MC (1986b) The oligodendrocyte-type-2 astrocyte cell lineage is specialized for myelination. Nature 323:335338.

ffrench-Constant C, Miller RH, Kruse J, Schachner M, Raff MC (1986) Molecular specialization of astrocyte processes at nodes of Ranvier in rat optic nerve. J Cell Biol 102:844-852.

Fulton BP, Burne JF, Raff MC (1991) Glial cells in the rat optic nerve The search for the type-2 astrocyte. Ann NY Acad Sci 633:27-34. 
Hanker JS, Yates PE, Metz CB, Rustioni A (1977) A new, specific, sensitive and non-carcinogenic reagent for the demonstration of horseradish peroxidase. Histochem J 9:789-792.

Hardy R, Reynolds R (1991) Proliferation and differentiation potential of rat forebrain oligodendroglial progenitors both in vitro and in vivo. Development 111:1061-1080.

Hildebrand C (1971) Ultrastructural and light-microscopic studies of the nodal region in large myelinated fibers of the adult feline spinal cord white matter. Acta Physiol Scand [Suppl] 364:43-71.

Hogan PG (1983) Expression of markers for pain sensory neurons in cell culture. $\mathrm{PhD}$ thesis, Harvard University.

Hollmann M, Hartley M, Heinemann S (1991) $\mathrm{Ca}^{2+}$ permeability of KA-AMPA-gated glutamate receptor channels depends on subunit composition. Science 252:851-853.

Huettner JE, Baughman RW (1986) Primary culture of identified neurons from the visual cortex of postnatal rats. J Neurosci 6:3044-3060.

Iino M, Ozawa S, Tsuzuki K (1990) Permeation of calcium through excitatory amino acid receptor channels in cultured rat hippocampal neurones. J Physiol (Lond) 424:151-165.

Janzer RC, Raff MC (1987) Astrocytes induce blood brain barrier properties in endothelial cells. Nature 325:253-257.

Kruse J, Keilhauer G, Faissner A, Timpl R, Schachner M (1985) The $\mathrm{J} 1$ glycoprotein - a novel nervous system cell adhesion molecule of the L2/HNK-1 family. Nature 316:146-148.

Levine JM, Card JP (1987) Light and electron microscopic localization of a cell surface antigen (NG2) in the rat cerebellum: association with smooth protoplasmic astrocytes. J Neurosci 7:2711-2720.

Levine JM, Stallcup WP (1987) Plasticity of developing cerebellar cells in vitro studied with antibodies against the NG2 antigen. J Neurosci 7:2721-2731.

LeVine SM, Goldman JE (1988a) Spatial and temporal patterns of oligodendrocyte differentiation in rat cerebrum and cerebellum. $J$ Comp Neurol 277:441-455.

LeVine SM, Goldman JE (1988b) Ultrastructural characteristics of $\mathrm{G}_{\mathrm{D} 3}$ ganglioside-positive immature glia in rat forcbrain white matter. J Comp Neurol 277:456-464.

Lillien LE, Raff MC (1990) Differentiation signals in the CNS: type2 astrocyte development in vitro as a model system. Neuron 5:111119.

Lillien LE, Sendtner M, Rohrer H, Hughes SM, Raff MC (1988) Type2 astrocyte development in rat brain cultures is initiated by a CNTFlike protein produced by type-1 astrocytes. Neuron $2: 485-494$.

Lin LFH, Mismer D, Lile JD, Armes LG, Butler ET, Vannice JL, Collins F (1989) Purification, cloning, and expression of ciliary neurotrophic factor (CNTF). Science 246:1023-1025.

Llinás R (1973) Procion yellow and cobalt as tools for the study of structure-function relationships in vertebrate central nervous system. In: Intracellular staining in neurobiology (Kater SB, Nicholson C, eds), pp 211-225. Berlin: Springer.

Marshak-Rothstein A, Fink P, Gridley T, Raulet DH, Bevan MJ, Gefter ML (1979) Properties and applications of monoclonal antibodies directed against determinants of the Thy-1 locus. J Immunol 122: 2491-2497.

McCarthy GF, Leblond CP (1988) Autoradiographic evidence for slow astrocyte turnover and modest oligodendrocyte production in the corpus callosum of adult mice injected with ${ }^{3} \mathrm{H}$-thymidine. J Comp Neurol 271:589-603.

Miller RH, David S, Patel R, Abney ER, Raff MC (1985) A quantitative immunohistochemical study of macroglial cell development in the rat optic nerve: in vivo evidence for two distinct glial cell lineages. Dev Biol 111:35-41.

Miller RH, Abney ER, David S, ffrench-Constant C, Lindsay R, Patel $R$, Stone J, Raff MC (1986) Is reactive gliosis a property of a distinct subpopulation of astrocytes? J Neurosci 6:22-29.

Miller RH, Fulton BP, Raff MC (1989) A novel type of glial cell associated with nodes of Ranvier in rat optic nerve. Eur J Neurosci $1: 172-180$.

Noble M, Wolswijk G, Wren D (1989) The complex relationship between cell division and differentiation in oligodendrocyte-type-2 astrocyte progenitor cells isolated from perinatal and adult rat optic nerve. Prog Growth Factor Res 1:179-194.

Perry VH, Gordon S (1988) Macrophages and microglia in the nervous system. Trends Neurosci 11:273-277.

Pesheva P, Speiss E, Schachner M (1989) J1-160 and J1-180 are oligodendrocyte-secreted nonpermissive substrates for cell adhesion. J Cell Biol 109:1765-1778.
Pitman RM, Tweedle CD, Cohen MJ (1972) Branching of central neurons: intracellular cobalt injection for light and electron microscopy. Science 176:412-414.

Pringle NP, Mudhar HS, Collarini EJ, Richardson WD (1992) PDGF receptors in the rat CNS: during late neurogenesis, PDGF $\alpha$-receptor expression appears to be restricted to glial cells of the oligodendrocyte lineage. Development 115:535-551.

Pruss RM (1979) Thy-1 antigen on astrocytes in long-term cultures of rat central nervous system. Nature 280:688-690.

Pruss RM, Akeson RL, Racke MM, Wilburn JL (1991) Agonist-activated cobalt uptake identifies divalent cation permeable kainate receptors on neurons and glial cells. Neuron 7:509-518.

Raff MC (1989) Glial cell diversification in the rat optic nerve. Science 243:1450-1455.

Raff MC, Abney ER, Cohen J, Lindsay R, Noble M (1983) Two types of astrocytes in cultures of developing rat white matter: differences in morphology, surface gangliosides and growth characteristics. J Neurosci 3:1289-1300.

Raff MC, Abney ER, Miller RH (1984) Two glial cell lineages diverge prenatally in the rat optic nerve. Dev Biol 106:53-60.

Raff MC, Abney ER, Fok-Seang J (1985) Reconstitution of a developmental clock in vitro: a critical role for astrocytes in the timing of oligodendrocyte differentiation. Cell 42:61-69.

Ramón-Moliner E (1958) A study of neuroglia. The problem of transitional forms. J Comp Neurol 110:157-171.

Ranscht B, Clapshaw PA, Price J, Noble M, Seifert W (1982) Development of oligodendrocytes and Schwann cells studied with a monoclonal antibody against galactocerebroside. Proc Natl Acad Sci USA 79:2709-2713.

Ransom BR, Butt AM, Black JA (1991) Ultrastructural identification of HRP-injected oligodendrocytes in the intact rat optic nerve. Glia 4:37-45.

Reyners H, Gianfelici de Reyners E, Maisin J-R (1982) The beta astrocyte: a newly recognized radiosensitive glial cell type in the cerebral cortcx. J Neurocytol 11:967-983.

Reyners H, Gianfelici de Reyners E, Regniers L, Maisin J-R (1986) A glial progenitor cell in the cerebral cortex of the adult rat. J Neurocytol 15:53-61.

Reynolds R, Wilkin GP (1988) Development of macroglial cells in rat cerebellum. II. An in situ immunohistochemical study of oligodendroglial lineage from precursor to mature myelinating cell. Development 102:409-425.

Richardson WD, Raff MC, Noble M (1991) The oligodendrocyte-type2-astrocyte lineage. Semin Neurosci 2:445-454.

Sendtner M, Kreutzberg GW, Thoenen H (1990) Ciliary neurotrophic factor prevents the degeneration of motor neurons after axotomy. Nature 345:440-441.

Skoff RP (1990) Gliogenesis in rat optic nerve: astrocytes are generated in a single wave beforc oligodendrocytcs. Dev Biol 139:149-168.

Skoff RP, Vaughn JE (1971) An autoradiographic study of proliferation in degenerating rat optic nerve. J Comp Neurol 141:133-156.

Skoff RP, Price DL, Stocks A (1976) Electron microscopic autoradiographic studies of gliogenesis in rat optic nerve. 2. Time of origin. $\mathrm{J}$ Comp Neurol 169:313-334.

Small RK, Riddle P, Noble M (1987) Evidence for migration of oligodendrocyte-type-2 astrocyte progenitor cells into the developing rat optic nerve. Nature 328:155-157.

Sommer I, Schachner M (1981) Monoclonal antibodies (O1-O4) for oligodendrocyte cell surfaces: an immunological study in the central nervous system. Dev Biol 83:311-327.

Stallcup WB, Beasley L (1987) Bipotential glial precursor cells of the optic nerve express the NG2 proteoglycan. J Neurosci 7:2737-2744.

Stöckli KA, Lillicn LE, Näher-Noé M, Breitfeld G, Hughes RA, Raff MC, Thoenen H, Sendtner M (1991) Regional distribution, developmental changes and cellular localization of CNTF-mRNA in the rat brain. J Cell Biol 115:447-459.

Suárez I, Raff MC (1989) Subpial and perivascular astrocytes associated with nodes of Ranvier in the rat optic nerve. J Neurocytol 18: 577-582.

Tyrer NM, Shaw MK, Altman JS (1980) Intensification of cobaltfilled neurons in sections (light and electron microscopy). In: Neuroanatomical techniques: insect nervous system (Strausfeld NJ, Miller TA, eds), pp 429-450. Berlin: Springer.

Usowicz MM, Gallo V, Cull-Candy SG (1989) Multiple conductance channels in type-2 cerebellar astrocytes activated by excitatory amino acids. Nature 339:380-383. 
Vaughn JE (1969) An electron microscopic analysis of gliogenesis in rat optic nerves. Z Zellforsch 94:293-324.

Vaughn JE, Peters A (1968) A third neuroglial cell type. An electron microscope study. J Comp Neurol 133:269-288.

Wolswijk G, Noble M (1989) Identification of an adult-specific glial progenitor cell. Development 105:387-400.

Wolswijk G, Noble N (1992) Co-operation between PDGF and FGF converts slowly dividing $\mathrm{O}-2 \mathrm{~A}^{\text {adult }}$ progenitor cells to rapidly dividing cells with characteristics of their perinatal counterparts. J Cell Biol 118:889-900.

Wolswijk G, Riddle PN, Noble M (1990) Coexistence of perinatal and adult forms of a glial progenitor cell during development of the rat optic nerve. Development 109:691-698.

Wolswijk G, Munro PMG, Riddle PN, Noble M (1991) Origin, growth factor responses and ultrastructural characteristics of an adult-specific glial progenitor cell. Ann NY Acad Sci 633:502-504.

Wood PM, Bunge RP (1991) The origin of remyelinating cells in the adult central nervous system: the role of the mature oligodendrocyte. Glia 4:225-232.

Wren D, Wolswijk G, Noble M (1992) In vitro analysis of the origin and maintenance of O-2A adult progenitor cells. J Cell Biol 116:167176.

Wyllie DJA, Cull-Candy DG (1992) Calcium permeability of glutamate receptor channels in rat cerebellar granule neurons and type-2 astrocytes in explant culture. J Physiol (Lond) 446:598P.

Wyllie DJA, Mathie A, Symonds CJ, Cull-Candy SG (1991) Activation of glutamate-receptors and glutamate-uptake in identified macroglial cells of the rat. J Physiol (Lond) 432:235-258. 